\title{
sciendo
}

Transport and Telecommunication, 2019, volume 20, no. 4, 325-345

Transport and Telecommunication Institute, Lomonosova 1, Riga, LV-1019, Latvia

DOI 10.2478/ttj-2019-0027

\section{THE APPLICATION OF ADAPTIVE NEURO-FUZZY INFERENCE SYSTEM AND FUZZY DELPHI TECHNIQUE TO ASSESS SOCIO-ECONOMIC IMPACTS OF CONSTRUCTION OF RURAL ROADS}

\author{
Makrand Wagale ${ }^{1}$ and Ajit Pratap Singh ${ }^{2 *}$ \\ ${ }^{1}$ Research Scholar, Department of Civil Engineering, BITS, Pilani-333031, India \\ ${ }^{2}$ Department of Civil Engineering, BITS, Pilani-333031, India \\ "aps@pilani.bits-pilani.ac.in
}

\begin{abstract}
One of the key elements for rural development is the connectivity using proper roads, which enhances the passage for economic and social utilities with overall socio-economic development. Socio-economic impact assessment (SEIA) forms one of the significant measures to evaluate the outcome received through infrastructure development in rural areas. SEIA modeling under computational intelligence coupled with fuzzy framework provides significant ground to deal with both qualitative and quantitative data. This study proposes a novel methodology by using Adaptive Neuro-Fuzzy Inference System (ANFIS) with Fuzzy Delphi method (FDM) to evaluate socio-economic impacts. The effectiveness of the methodology is presented through a case study for 27 habitations connected with all-weather rural roads constructed under Pradhan Mantri Gram Sadak Yojana (PMGSY) scheme in Jhunjhunu district of Rajasthan State, India. 33 key-parameters under five different criteria are considered for SEIA. For a comprehensive view of the impacts, the results are depicted using ArcGIS tool.
\end{abstract}

Keywords: Adaptive Neuro-Fuzzy Inference System, accessibility, socio-economic impact assessment (SEIA), transportation

\section{Introduction}

Roads are recognized as a significant component for the social and economic development of rural areas. Moreover, an improved transport infrastructure often provides access to market and public services (health, education) for rural residents. Rural roads play an important role in the overall development of the isolated communities/habitations thereby enhancing their connectivity to nearest economic/market centers. Development of rural road infrastructure in case of developing countries can have a significant impact on the target population; it brings out economic growth with poverty alleviation (Banister and Berechman, 2000; Khandker et al., 2009). In developing countries like India, there is an emphasis on improving rural road infrastructure. It can be seen from the initiatives taken by the Government of India. One such initiative is the launch of Pradhan Mantri Gram Sadak Yojana (PMGSY) scheme in December 2000 to connect rural habitations to nearest markets. Transport infrastructure is a primary means of economic development which pave access to the markets for the agricultural produce of the rural community (Asomani-Boateng et al., 2015).

To a certain level, change in the socio-economic status of rural habitation is dependent on the circumstances or conditions of travel and access (Kanuganti et al., 2015). Tunde and Adeniyi (2012) tried to show that with the improvement in the road quality, there is a decrease in the transportation cost of agricultural products; thereby increasing the profit and income of the farmers. Traditionally, transportation projects are justified based on economic efficiency and are evaluated by considering a costbenefit analysis. Most of the attempts are focused towards economic consideration; only a few are efficiently designed to assess social and economic impacts attributed by rural roads separately (Grootaert and Calvo, 2002; Aderamo and Magaji, 2010). Nirban et al. (2003) indicated the necessity of identifying the variables which can quantify (direct and indirect) socio-economic benefits incurred by the rural households. Khandker and Koolwal (2011) performed a study to distinguish the long-term and short-term effects of rural road infrastructure. The authors evaluated the change in financial gains of the most socioeconomically backward class of the population.

Improvements in rural roads assist in achieving both economic and social benefits. Therefore, there is a need to quantify socio-economic impacts in a comprehensive manner, which can demonstrate how the availability of all-weather rural road infrastructure promotes both direct and indirect benefits to the society. For effective assessment, it is necessary to have a proper understanding of socio-economic 
impacts (SEI) derived from the developed road infrastructure. Socio-economic impact assessment involves both qualitative and quantitative methods of assessment. Quantitative methods such as randomization, reflexive comparisons, matching, double differences, etc. are employed to assess the socio-economic impacts incurred conventionally. Randomization method is considered to be the most robust among impact evaluation methodologies. Quantitative methods, viz., reflexive comparisons, matching, double differences, etc. can deliver better understanding about SEI, provided appropriate data set is available, these are cost effective and less time consuming, and can be performed Nower the deliverance of road infrastructure (Baker, 2000). In case of cost-benefit analysis, attempts are made to assess the benefits incurred in terms of monetary returns.

Quantitative methods mentioned above for socio-economic impact evaluations reach generalized conclusions; they require specialized skills and expertise. In comparison to quantitative techniques, qualitative methods provide profound insight into the incurred impacts. Qualitative analyses are more perceptible and are based on focus group (community) surveys, household surveys, etc. which involves the target population as decision makers. Such group decision making can be performed using several methods, the most popular being Delphi method (Dalkey and Helmer, 1963). It incorporates the judgments provided by the group of participants involved in the decision-making process by means of questionnaires. Moreover, when traditional Delphi approach is integrated with the fuzzy set theory, it overcomes the inconsistency and risks associated with the conventional method and helps in reducing the time and cost associated with overall questionnaire survey process (Hsu et al., 2010). It also assists in the group decision-making process in a comprehensive manner by overcoming the fuzziness associated with opinions of decision makers (Singh and Vidyarthi, 2008; Kanuganti et al., 2016).

Although, different quantitative and qualitative methods are used for assessing socio-economic impacts, the main problem is the modeling of human perceptions under given circumstances as well as some of the techniques mentioned above (i.e., Randomization, matching, cost-benefit analysis, etc.) are cost and time-consuming. They lack in integrating the uncertainties that may arise in the data set which are dependent on the viewpoints of the target population, leading to considerable bias assessment. For this reason, researchers are being encouraged to employ comprehensive methods/techniques for assessing the impacts incurred. In recent times researchers are focused on adopting innovative techniques and methodologies to assess various issues associated with transportation studies (road infrastructure, traffic studies, etc.). Among the new techniques, Computational Intelligence (CI) approach offers factual advantages and are becoming popular, as it can handle complexity associated with the information to be acquired from the data set collected specially to enhance the effectiveness and environmental coherence of transportation system. As each of these techniques is proven as effective when employed.

However, when they can be exploited in a symbiotic manner, they prove to be as powerful intelligent decision support system (Akbulut et al., 2004). Adaptive Neuro-Fuzzy Inference System (ANFIS) is one such technique. It is developed by integrating neural networks and fuzzy logic. ANFIS captures the benefits of both neural networks and fuzzy logic and eliminates their shortcomings respectively. ANFIS technique allows in strategic decision making with high-level proficiency in a systematic manner. It is widely used in condition identification (Hosseinlou and Sohrabi, 2009), decision making (Pamučar et al., 2013), prediction modeling (Lee et al., 2015), etc. It provides results with a tolerance of ambiguity, uncertainty, approximation and handle complex social and human systems comprehensively by utilizing linguistic information in the form of human perception and measured data (Islam et al., 2016), as well as it is time and cost effective. Thus, it is well understood that the ANFIS technique can overcome the existing research shortcomings in the available techniques employed to assess socio-economic impacts thoroughly. It can be a significant value addition to the literature available on SEI instigated by road infrastructure.

Therefore, the present study attempts to develops a holistic framework to assess the socioeconomic impacts (SEI) incurred by the target population due to the construction of rural roads by employing ANFIS and fuzzy Delphi method. It considers their prolific nature and efficiency of evaluation. Furthermore, it also presents a comparison of the evaluation capabilities of ANFIS and fuzzy Delphi techniques. The key objective of this research is two-fold: (a) to assess and highlight how the construction of rural (PMGSY) roads impacts the socio-economic status of rural habitations by employing computational intelligence and soft computing approach, and (b) to explore and exploit the evaluation capabilities of above mention approaches by developing novel framework, thereby paving a way to the decision and policy makers to implement essential policies. The effectiveness of methodology is presented by employing a case study for 27 habitations connected through rural (PMGSY) roads constructed in the year 2013-14 in Jhunjhunu district of Rajasthan state, India. A total of five main criteria and 33 sub-criteria are considered for socio-economic impact assessment (SEIA) to demonstrate the cause-effect relationships. The methodology presented herein is capable of efficiently dealing with the complexities that may result in group decision-making process. 


\section{Methodology}

The present study proposes a methodology by employing a case study approach for selected habitations of Jhunjhunu district of Rajasthan state, India, to evaluate socio-economic impacts on rural habitations/communities due to the deliverance of rural road infrastructure. The current study is based on ex-post research design (i.e., after the construction of roads), as the objective is to identify the actual impacts of roads after their construction, and to draw the valuable insights from the assessment that how much the change has occurred. The approach focuses on identifying and measuring the net impacts occurred based on the perception of impacted population and statistical control comparison (Braathen and Hervik, 1997). The ex-post evaluation approach mainly focuses on two aspects: (i) impact - which is expected to appear after a certain period of time after the roads are being delivered, and (ii) sustainability - whether the impacts are continuously produced after the implementation of the project. The ex-post approach helps in investigating the effectiveness of implementation of construction of roads by evaluating improvement effects in the social and economic conditions of rural households (Louwa et al., 2013). The ex-post approach also helps in checking the assumptions made earlier that impacts are expected to occur after some time period after the roads are constructed.

Thus, present study focuses on assessing and measuring the impacts based ex-post approach by considering the perception of rural households as no control group for statistical comparison. Therefore, from assessment design point of view, only those habitations are identified where the roads are intended to improve the socio-economic condition of rural inhabitants. In the current research, ANFIS using the subtractive algorithm as well as fuzzy Delphi method (FDM) are employed to assess the socio-economic impacts incurred by the construction of rural roads. Furthermore, the results of ANFIS is compared with results obtained from FDM, to assess their computational capabilities.

\subsection{Selection of study area and SEIA criteria/sub-criteria}

\section{Study area}

A case study is taken for the habitations connected by PMGSY roads in 6 (out of 8) blocks of Jhunjhunu district, Rajasthan, India. Total 27 roads are considered along the selected habitations as shown in Figure 1. The sampling of these roads defining the study area is adjusted based on factors such as the year of their construction (i.e., PMGSY roads constructed in 2013-14 are selected) as most socioeconomic changes take time to occur. The roads are also selected based on the population of habitations as well as geographical location. The population of these habitations ranges from 350 to 390 . The habitations selected belong to the arid region of the state, which has extreme climatic conditions with very hot summers and very cold winters followed by poor rainfall. Map of blocks of Jhunjhunu district representing through routes and habitations location considered for study are shown below in Figure 1. Table 1 below shows different blocks and habitations of Jhunjhunu district, Rajasthan state, India considered for the study.

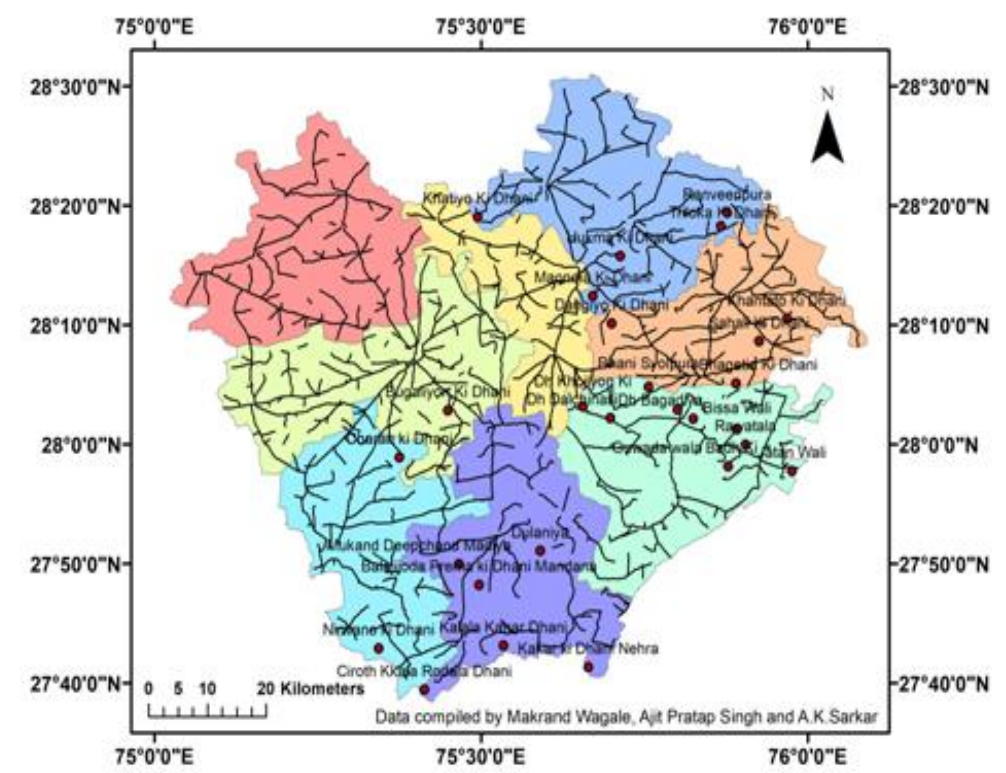

Figure 1. Map of blocks of Jhunjhunu district with through routes and habitations location 
Table 1. Blocks and habitations of Jhunjhunu district, Rajasthan, India (study area)

\begin{tabular}{|c|c|c|}
\hline Block & Habitation & Population \\
\hline \multirow{4}{*}{ Buhana } & Bhagatia Ki Dhani & 350 \\
\hline & Dangiyo Ki Dhani & 390 \\
\hline & Sahali Ki Dhani & 390 \\
\hline & Khantato Ki Dhani & 360 \\
\hline Jhunjhunu & Bugaliyon Ki Dhani & 375 \\
\hline \multirow{9}{*}{ Khetri } & Jatan Wali Dhani & 350 \\
\hline & Dhani Syolpura & 350 \\
\hline & Dhani Dalchinasi & 350 \\
\hline & Dhani Khojiyon Ki & 350 \\
\hline & Bissa Wali Dhani & 350 \\
\hline & Dhani Adhana Ki & 350 \\
\hline & Dhani Bagadiya & 350 \\
\hline & Guwada wala Badh Ki & 350 \\
\hline & Rawatala & 350 \\
\hline \multirow{5}{*}{ Surajgarh } & Ranveenpura & 350 \\
\hline & Triloka Ki Dhani & 360 \\
\hline & Maondia Ki Dhani & 350 \\
\hline & Khatiyo Ki Dhani & 350 \\
\hline & Hukma Ki Dhani & 350 \\
\hline \multirow{2}{*}{ Nawalgarh } & Nirwano ki Dhani & 370 \\
\hline & Charan ki Dhani & 350 \\
\hline \multirow{6}{*}{ Udaipurwati } & Kalala Kahar Dhani & 350 \\
\hline & Ciroth Kkala Rodala Dhani & 350 \\
\hline & Kakar ki Dhani Nehra & 350 \\
\hline & Dulaniya & 360 \\
\hline & Balajijoda Prema ki Dhani & 375 \\
\hline & Mukand Deepchand Madiya & 360 \\
\hline
\end{tabular}

\section{SEIA criteria/sub-criteria selection}

Socio-economic criteria are used to assess social and economic phenomenon of a community. They provide an insight into the likely impacts of delivered infrastructure on the target community or population and help in monitoring the development. The identification of all-important criteria requires a sound knowledge of the subject and expert's input. It is a process which involves complexity and can be handled by developing a systematic methodology by integrating available existing research (Grootaert and Calvo, 2002; Khandker et al., 2009; Aderamo and Magaji, 2010) with technical advice from experts (researchers, policy and decision makers) as well as all preliminary survey. The study follows a systematic method in selecting important SEIA criteria as shown in Figure 2. Initially, the study focuses on the available scientific literature (Grootaert and Calvo, 2002; Khandker et al., 2009; Aderamo and Magaji, 2010), to gather necessary information on socio-economic criteria/sub-criteria useful for assessing the change in social and economic phenomenon of rural households due to construction of road infrastructure. Next, the opinions from the expert group are captured through a participatory approach. This expert group consisted of a team of five members belonging to academia and research institutes, government organization, and professionals/authorities working in the field of rural development schemes. The experts are asked to provide importance of each criteria which are required to assess the impacts (as per Appendix I), on a scale of 1 to 5, where, $1=$ not important at all and $5=$ very important. It is then combined to arrive at aggregate score, which is then used to identify criteria/sub-criteria for assessment. A preliminary survey is also conducted at few selected habitations to understand ground reality of importance of each criterion. Finally, a concise set with 33 sub-criteria under five main criteria, viz., transport facility, income status, health facility, education facility and quality of the neighborhood has been identified. SEIA criteria (alternatives) along with sub-criteria considered for the study is given in Table 2. 


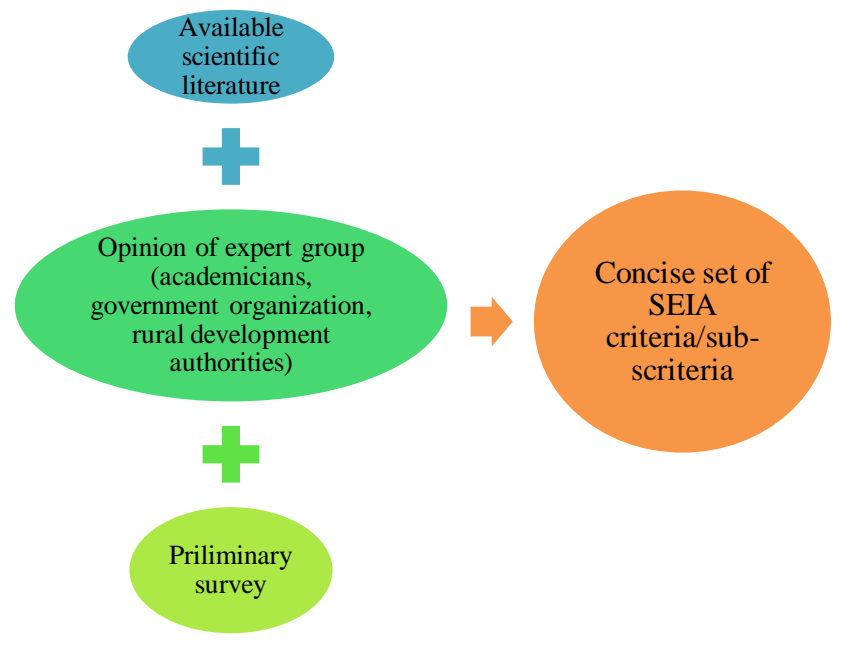

Figure 2. Steps followed in selecting important SEIA criteria

Table 2. Socio-economic impact assessment criteria and sub-criteria with symbols

\begin{tabular}{|c|c|c|}
\hline Criteria & Sub-criteria & Symbol \\
\hline \multirow{7}{*}{ Transport facility } & Travel time using public transportation & $\mathrm{T}_{\text {TTPUB }}$ \\
\hline & Travel time using private transportation & $\mathrm{T}_{\text {TTPVT }}$ \\
\hline & Public transportation units & $\mathrm{T}_{\text {PUBTU }}$ \\
\hline & Private transportation units & $\mathrm{T}_{\mathrm{PVTTU}}$ \\
\hline & Frequency of public transportation & $\mathrm{T}_{\mathrm{PUBF}}$ \\
\hline & Public transportation cost & $\mathrm{T}_{\text {PUBTC }}$ \\
\hline & Private transportation cost & $\mathrm{T}_{\mathrm{PVTTC}}$ \\
\hline \multirow{7}{*}{ Income status } & Income Individual & $\mathrm{I}_{\mathrm{II}}$ \\
\hline & Income of household & $\mathrm{I}_{\mathrm{IHH}}$ \\
\hline & Income of self-employed from agriculture & $\mathrm{I}_{\mathrm{ISA}}$ \\
\hline & Income of wage labor from agriculture & $\mathrm{I}_{\mathrm{IWA}}$ \\
\hline & Income from livestock & $\mathrm{I}_{\mathrm{IL}}$ \\
\hline & Income of unskilled labor from agriculture & $\mathrm{I}_{\mathrm{IUA}}$ \\
\hline & Income of unskilled labor from non-agriculture & $\mathrm{I}_{\mathrm{IUNA}}$ \\
\hline \multirow{6}{*}{ Health facility } & Use of health facility & $\mathrm{H}_{\mathrm{FU}}$ \\
\hline & Availability of health clinic & $\mathrm{H}_{\mathrm{CA}}$ \\
\hline & Availability of primary health center & $\mathrm{H}_{\mathrm{PHCA}}$ \\
\hline & Access to the mode of transport for health facility & $\mathrm{H}_{\text {HAM }}$ \\
\hline & Travel time to reach a health facility & $\mathrm{H}_{\mathrm{TT}}$ \\
\hline & Health Status (anthropometric measures up to adolescent age) & $\mathrm{H}_{\text {HSANT }}$ \\
\hline \multirow{8}{*}{ Education Facility } & Literacy rate of male & $\mathrm{E}_{\mathrm{MLR}}$ \\
\hline & Literacy rate of female & $\mathrm{E}_{\mathrm{FLR}}$ \\
\hline & Percent of male children attending schools & $\mathrm{E}_{\mathrm{MAS}}$ \\
\hline & Percent of female children attending schools & $\mathrm{E}_{\mathrm{FAS}}$ \\
\hline & Access to the mode of transport for education facility & $\mathrm{E}_{\mathrm{AM}}$ \\
\hline & Travel time to reach education facility & $\mathrm{E}_{\mathrm{TT}}$ \\
\hline & Availability of preschools & $\mathrm{E}_{\text {PRESA }}$ \\
\hline & Availability of primary schools & ERISA $_{\text {PRA }}$ \\
\hline \multirow{5}{*}{ Quality of Neighborhood } & Ownership of personal phone & $\mathrm{QPPO}_{\mathrm{PPO}}$ \\
\hline & Ownership of television & $\mathrm{Q}_{\mathrm{TVO}}$ \\
\hline & Livability & $\mathrm{Q}_{\mathrm{L}}$ \\
\hline & Involvement in social-gathering within the village & $\mathrm{Q}_{\mathrm{SGIV}}$ \\
\hline & Involvement in social-gathering outside the village & $\mathrm{Q}_{\mathrm{sGOV}}$ \\
\hline
\end{tabular}

It is to be noted that the indicators such as "income from livestock" or "ownership of television" or "ownership of personal phone" relate to the improvements in income and quality of life of rural 
inhabitants after the construction of roads, as these habitations have been at remote places and had low accessibility to new avenues of income and personal recreation possessions. It has been observed that if roads are provided, villagers have better accessibility and hence they may have better employment. Thus their living standards are improved which can be assessed directly or indirectly by correlating even by income from livestock or ownership of television or ownership of personal phone. All these variables become even more important in case of developing worlds. As variables such as safety, air quality, noise mainly used to assess environmental impacts of road construction, they have not been taken into consideration in this study.

\subsection{Methods and material}

\section{ANFIS- employing subtractive clustering algorithm}

Artificial Intelligence (AI) approach is broadly categorized into two sections, one which concentrates on the development of the knowledge-based system (KBS) and the other is computational intelligence. Among computational intelligence techniques, neural networks have an intrinsic tendency in storing the acquired pragmatic information which can be used by the researchers in various real-life applications (Wagale et al., 2016). These techniques can simulate the output results in a robust manner using the concepts of biological nervous system and can reproduce numerical paradigms. However, recently a hybrid methodology of neural networks called Adaptive Neuro-fuzzy Inference System (ANFIS) is becoming popular due to its ability to address very complex problems. This technique is the integration of neural network learning algorithms along with fuzzy based inference system. Application of ANFIS is well implemented successfully in numerous areas of transportation studies, viz., travel behaviour and mode choice modelling, estimation of ques lengths at signalized intersections, road accident and traffic flow prediction modelling (Pribyl and Goulias, 2003; Andrade et al., 2006; Tortum et al., 2009; Mucsi et al., 2011; Lee et al., 2015). ANFIS is one of the most innovative techniques of artificial intelligence employed to quantify real-life situations by incorporating substantial human perceptions using appropriate data sets and their interrelationships.

The hybrid approach can be applied for constructing complex and nonlinear relationships among a given set of data points (input and output data set). As ANFIS approach is the integration of fuzzy inference system (FIS) and artificial neural networks (ANN) it takes into account the operations of both FIS and ANN (Jang, 1993). Thus, in ANFIS modeling, a strategic system is developed which combines significant aspects of both FIS and ANN respectively. Many researchers have developed fuzzy inference methodologies by deriving IF-THEN rules that are widely used in assessing different problems under the uncertain environment (Mamdani and Assilian, 1975; Takagi and Sugeno, 1985). Takagi and Sugeno's FIS model is expressed in the form of a constant coefficient or a linear equation with "zero order" or "first-order" Sugeno models respectively. Logically ANFIS employs Sugeno fuzzy inference system to develop fuzzy rules with a given dataset. Fuzzy rules (IF/THEN) in ANFIS for first-order Sugeno fuzzy inference system consisting of two inputs $(X)$ and $(Y)$ with single output $(f)$ can be expressed as:

Rule 1: IF $X$ is $A_{1}$ and $Y$ is $B_{1}$, THEN $f_{1}=l_{1} X+m_{1} Y+n_{1}$

Rule 2: IF X is $A_{2}$ and $Y$ is $B_{2}$, THEN $f_{2}=l_{2} X+m_{2} Y+n_{2}$

where $A_{1}, A_{2}, B_{1}$, and $B_{2}$ are linguistic labels and $l_{1}, l_{2}, m_{1}, m_{2}, n_{1}$, and $n_{2}$ are linear parameters.

The ANFIS architecture consists of five-layers as shown above in Figure 3. The layers are connected with direct links and nodes representing different shapes and utilities. The circular nodes in the architecture depict fixed type nodes, whereas square nodes represent adaptive nodes. The layer-wise process followed in ANFIS is elucidated as below:

Layer 1 (Fuzzification): This layer develops membership functions by the fuzzy sets; input attributes are introduced in this layer. Every node of this layer is an adaptive node. The input and the output functions along with their membership relation are expressed in equation (1) and equation (2) as given below:

$O_{i}^{1}=\mu_{A i}(X) ; i=1,2$,

$O_{j}^{1}=\mu_{B i}(Y) ; i=1,2$,

where $X$ and $Y$ are the inputs in layer 1 to the adaptive nodes $A_{i}$ and $B_{j}$ respectively, which represent linguistic terms of input criteria, $\mu_{A i}(X)$ and $\mu_{B i}(Y)$ are the membership functions of $A i$ and $B j$ respectively. 


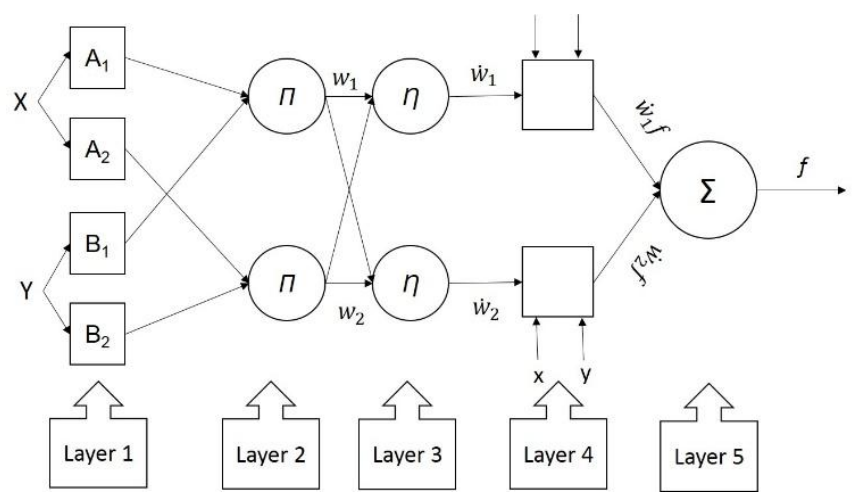

Figure 3. The generalized model architecture of ANFIS

Layer 2 (Fuzzy AND): The layer produces the output which depends upon the fuzzy input of the preceding layer by activating necessary fuzzy rules. It is labeled as $(\Pi)$ and performs product operation. The output of this layer $\left(o_{i}^{2}\right)$ (firing strength) is the degree to which the developed rule matches the given inputs and is given in equation (3) as mentioned below:

$O_{i}^{2}=w_{i}=\mu_{A i}(X) \mu_{B i}(Y) ; i=1,2$,

where $w_{i}$ is the firing strength.

Layer 3 (Normalization): This layer performs normalization of the fuzzy rule extent and is represented as $(I)$. The output of this layer $\left(o_{i}^{3}\right)$ are normalized and is expressed in equation (4) as given below:

$O_{i}^{3}=\dot{w}_{i}=\frac{w_{i}}{\sum w_{i}} ; i=1,2$,

where $\dot{w}_{i}$ is the ratio of firing strength to the summation firing strengths.

Layer 4 (Defuzzification): The fourth layer of the architecture evaluates the inputs provided by each fuzzy rule contributing to the output. In this layer, the nodes are adaptive nodes. The output of this layer $\left(o_{i}^{4}\right)$ is the product of normalized outputs of the previous layer and are of first order polynomial. The output of this layer is given in equation (5) as mentioned below:

$O_{i}^{4}=\dot{w}_{i} f=\dot{w}_{i}\left(l_{i} X+m_{i} Y+n_{i}\right) ; i=1,2$,

where $f$ is the output of the $i^{\text {th }}$ rule.

Layer 5 (Output layer): Finally, the fifth layer gives overall output by considering all the inputs from the previous layers. This layer consists of a single fixed node $(\Sigma)$ which performs the summation of all the inputs coming from previous layers to give overall output $\left(o_{i}^{5}\right)$ of the model and is expressed in equation (6) as mentioned below:

$O_{i}^{4}=\sum_{i=1}^{2} \dot{w}_{i} f ; i=1,2$.

\section{Subtractive clustering algorithm}

The most important step in the ANFIS modelling is the determination of an optimum number of fuzzy rules required to obtain the desired output. For instance, if there are six input values with three membership grades, the number of rules will be $\left(3^{6}=729\right)$ which is quite large for any learning techniques to comprehend. It may increase further with an increase in input variables, thus leading to the problem of "curse of dimensionality". To overcome this problem of "curse of dimensionality" associated with ANFIS operation; subtractive clustering approach can be useful which is based on the concentration of data points and their closeness with the actual values. The main steps of the algorithm can be briefed as follows. First, it chooses the data point among the data set having maximum aptitude as the first cluster center. Next, it eliminates all the data points neighboring the first cluster with consideration to a range of influence (usually 0.5), and lastly, it performs iteration process such that every data point are contained within the radii of the cluster axis (considered to be 1.25). Table 3 represents the sample parameters considered for the subtractive clustering algorithm, which are taken based on literature available on ANFIS using subtractive clustering algorithm (Relich and Pawlewski, 2016). 
Table 3. Subtractive clustering parameters

\begin{tabular}{|l|l|l|}
\hline S. No. & Name & Value \\
\hline 1 & Range of influence & 0.3 \\
\hline 2 & Squash factor & 1.25 \\
\hline 3 & Accept ratio & 0.5 \\
\hline 4 & Reject ratio & 0.15 \\
\hline
\end{tabular}

\section{Fuzzy Delphi method}

Edelman (1985) proposed the concept of fuzzy set theory along with its integration to the traditional Delphi method to overcome the vagueness and uncertainty associated with the group decision-making process. Kaufmann and Gupta (1988) have also presented an application of fuzzy Delphi method in a group decision-making process. Chang and Wei (2000) concluded that fuzzy Delphi method provides an opportunity to overcome the uncertainty (fuzziness) arising from the perception of decision makers in optimizing the objectives. Fuzzy Delphi method can also overcome the number of survey rounds required to attain common consensus in the group decision-making process; it also reduces expenditure and duration incurred for the execution of group decision-making process by maintaining its originality as compared to that of traditional Delphi approach (Hsu et al., 2010). In the present study application of fuzzy Delphi method is performed by employing triangular fuzzy numbers to assess the perceptions of stakeholders (focus group participants). The stepwise procedure of fuzzy Delphi method is explained below.

Step: 1 Collection of perception of stakeholders (focus group participants)

A focus group survey is conducted for assessing the socio-economic impacts of PMGSY roads by considering five main criteria and 33 sub-criteria as key factors. The perceptions of stakeholders (focus groups participants) are taken as assessments scores in correspondence with each criterion. Each of the sub-criteria concerning main criteria is assessed on a scale of 5 down to 1 (i.e., $5=$ highest change; $1=$ lowest change). The range value of change scale is established by taking the opinion of experts working in this field and is deduced after interacting with their suggestions. Further, for ease of assessment and removal of geometrical biases associated with dimensions of the input data, and to smoothen from the influence of criteria on one another. This collected data is normalized on the scale varying in range of $0-1$. The min-max normalization technique is used for transforming data linearly from the scale of $1-5$ to $0-1$, as specified in equation (7) (Phogat and Singh, 2013):

$x_{\text {norm }}=\frac{\left(x_{i}-x_{\min }\right)}{\left(x_{\max }-x_{\min }\right)} ; i=1,2, \ldots, \mathrm{k}$,

where $x_{i}=i$ th scale value of the criteria, $x_{n o r m}=$ Normalized scale value of criteria, $x_{\min }=$ Minimum scale value of the criteria, and $x_{\max }=$ Maximum scale value of criteria.

Step: 2 Setting up triangular fuzzy numbers

In the present study, the triangular fuzzy number for each of the sub-criteria is evaluated based on the change scale scores obtained from the focus groups, after the process of normalization. The reason for adopting the triangular fuzzy scale is the dynamic change in the scaled valued of perception of stakeholders. The triangular fuzzy number is the best suitable for representing when there is dynamic variation and can be deduced with simplicity in comparison with other fuzzy scales such as trapezoidal, Gaussian etc. (Liu, 2013). The study also considers the literature (Liu, 2013; Tahriri et al., 2014) available on FDM which employed triangular fuzzy scale. The triangular fuzzy scale for study adopted is represented below in Figure 4. Table 4 shows the linguistic definition of triangular fuzzy numbers.

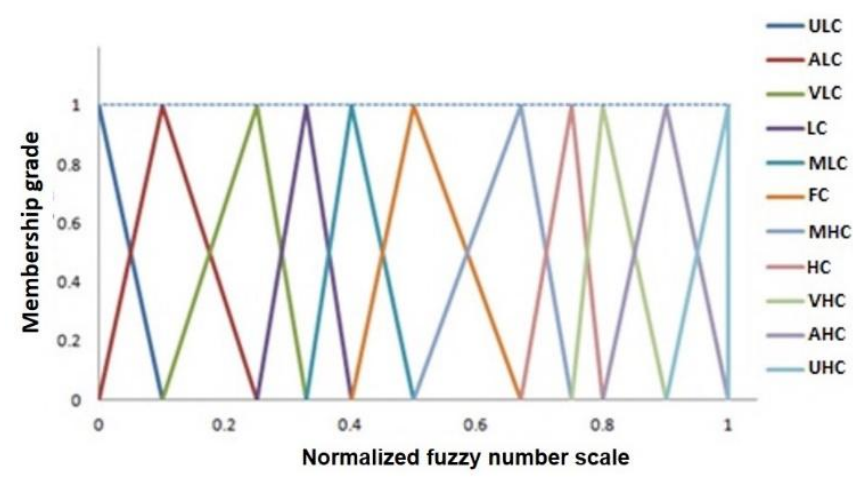

Figure 4. The fuzzy number scale 
Table 4. Definition of fuzzy numbers

\begin{tabular}{|l|l|l|}
\hline Fuzzy numbers & Definition & Symbol \\
\hline$(0.9,1,1)$ & Ultimate high category & UHC \\
\hline$(0.8,0.9,1)$ & Absolutely high category & AHC \\
\hline$(0.75,0.8,0.9)$ & Very high category & VHC \\
\hline$(0.67,0.75,0.8)$ & High category & HC \\
\hline$(0.5,0.67,0.75)$ & Moderate high category & MHC \\
\hline$(0.4,0.5,0.67)$ & Fair category & FC \\
\hline$(0.33,0.4,0.5)$ & Moderate low category & MLC \\
\hline$(0.25,0.33,0.4)$ & Low category & LC \\
\hline$(0.1,0.25,0.33)$ & Very low category & VLC \\
\hline$(0,0.1,0.25)$ & Absolutely low category & ALC \\
\hline$(0,0,0.1)$ & Ultimate low category & ULC \\
\hline
\end{tabular}

Step: 3 Aggregation of perceptions

In this step, the mean fuzzy weights for each of the sub-criteria are evaluated. This can be illustrated as follows: suppose $\left(w_{t}\right)$ is the categorical weight of the sub-criteria $\left(\mathrm{C}_{1}, \mathrm{C}_{2}, \mathrm{C}_{3}, \ldots, \mathrm{C}_{\mathrm{n}}\right)$ given by the stakeholder $S_{j}$ then the aggregation of stakeholders is formulated in equation (8) given below:

$S_{i j}=\left(\frac{1}{m}\right) \otimes\left(S_{i j}^{1} \oplus S_{i j}^{2} \oplus \ldots \ldots \oplus S_{i j}^{m}\right)$,

where $\otimes$ represents multiplication of fuzzy numbers and $\bigoplus$ represents the addition process of fuzzy numbers, $S_{i j}$ is the mean fuzzy evaluation of alternative $\mathrm{i}$ under sub-criterion $\mathrm{j}$ and is represented as triangular fuzzy number as shown below.

$S_{i j}=\left(p S_{i j}, q S_{i j}, r S_{i j}\right)$,

where $p S_{i j}=\left(\frac{\sum_{i j}^{m} p S_{i j}^{k}}{m}\right), q S_{i j}=\left(\frac{\sum_{i j}^{m} q S_{i j}^{k}}{m}\right), r S_{i j}=\left(\frac{\sum_{i j}^{m} r S_{i j}^{k}}{m}\right)$,

Then fuzzy weight $\widetilde{w}_{t}$ of the jth sub-criterion is $\widetilde{w}_{\mathrm{t}}=(\mathrm{at}, \mathrm{bt}, \mathrm{ct}) ; \mathrm{t}=1,2, \ldots, \mathrm{k}$.

Step: 4 Defuzzification of fuzzy weights

Finally, the synthetic fuzzy weight for each sub-criterion concerning each criterion are defuzzified to establish best non-fuzzy performance score (real number) (BNS). In the present study, the center of area technique is used to perform defuzzification process. The deffuzified scores BNS can be obtained by using equation (9) as given below.

$$
B N S_{i j}=\left[\frac{\left(r S_{i j}-p S_{i j}\right)+\left(q S_{i j}-p S_{i j}\right)}{3}\right]+p S_{i j}
$$

\subsection{Sampling and acquisition of input data}

\section{Determination of sample}

In the present study, sample determination is conducted in reference with past studies (AsomaniBoateng et al., 2015; Wagale et al., 2019). Sample population (focus group) for data collection of the study is adjusted with the population of each habitation, as well as, according to the selected PMGSY roads. The selected sample resembles the total population of each habitation. The study employs a stratified random sampling technique. The total population served by these roads is 9640 individuals, which is identified from the secondary source. The number of habitations considered for the study are proportional to the number of PMGSY roads identified. Therefore, considering $95 \%$ confidence level and $5 \%$ of margin error, a sample size of $n=369$ individuals is identified to have data as defined as possible (i.e., for each of the habitation one focus group is selected. Thus, making total 27 focus groups, such that each of the focus group consists of 14 participants as shown in Table 5). Also, each of the focus groups is identified in such a way that it involves participants belonging to a different gender (male and female), age group (i.e., 16 to 45), and livelihoods (e.g., agriculture, jobs such as peons, clerks, school teachers, students, etc.). 
Table 5. Coverage of study area (blocks and habitations of Jhunjhunu district, Rajasthan, India)

\begin{tabular}{|c|c|c|c|}
\hline Block & Habitation & Focus group size & Region total \\
\hline \multirow{4}{*}{ Buhana } & Bhagatia Ki Dhani & 14 & \multirow{4}{*}{56} \\
\hline & Dangiyo Ki Dhani & 14 & \\
\hline & Sahali Ki Dhani & 14 & \\
\hline & Khantato Ki Dhani & 14 & \\
\hline Jhunjhunu & Bugaliyon Ki Dhani & 14 & 14 \\
\hline \multirow{9}{*}{ Khetri } & Jatan Wali Dhani & 14 & \multirow{9}{*}{126} \\
\hline & Dhani Syolpura & 14 & \\
\hline & Dhani Dalchinasi & 14 & \\
\hline & Dhani Khojiyon Ki & 14 & \\
\hline & Bissa Wali Dhani & 14 & \\
\hline & Dhani Adhana Ki & 14 & \\
\hline & Dhani Bagadiya & 14 & \\
\hline & Guwada wala Badh Ki Dhani & 14 & \\
\hline & Rawatala & 14 & \\
\hline \multirow{5}{*}{ Surajgarh } & Ranveenpura & 14 & \multirow{5}{*}{70} \\
\hline & Triloka Ki Dhani & 14 & \\
\hline & Maondia Ki Dhani & 14 & \\
\hline & Khatiyo Ki Dhani & 14 & \\
\hline & Hukma Ki Dhani & 14 & \\
\hline \multirow[b]{2}{*}{ Nawalgarh } & Nirwano ki Dhani & 14 & \multirow[b]{2}{*}{28} \\
\hline & Charan ki Dhani & 14 & \\
\hline \multirow{6}{*}{ Udaipurwati } & Kalala Kahar Dhani & 14 & \multirow{6}{*}{84} \\
\hline & Ciroth Kkala Rodala Dhani & 14 & \\
\hline & Kakar ki Dhani Nehra & 14 & \\
\hline & Dulaniya & 14 & \\
\hline & Balajijoda Prema ki Dhani & 14 & \\
\hline & Mukand Deepchand Madiya & 14 & \\
\hline
\end{tabular}

\section{Acquisition of data}

The study employs a case study for habitations belonging to 6 (out of 8) different blocks of Jhunjhunu district of Rajasthan, India. Data about various indicators which define SEIA is collected through focus group survey from the identified habitations, connected by rural (PMGSY) roads. The focus group survey is conducted during (April and May 2016). To have the knowledge and to overcome the risks associated with data collection, preliminary discussions with rural inhabitants of the selected habitations are also conducted. Focus group surveys are facilitated by using a questionnaire, designed to collect data of both qualitative and quantitative nature; it also considers the inputs from preliminary discussions conducted before the final focus group discussion. It consists of five sections; each section represents criteria, which influence the socio-economic development of the rural inhabitants.

The questionnaire (Table 6) for the focus group survey is formulated with closed-ended questions to gauge necessary information in terms of categorical manner. To avoid indulgence of error in the data while conducting a focus group survey feedback are taken at the end of every section of the questionnaire as a crosscheck.

Table 6. Questionnaire information

\begin{tabular}{|c|c|c|c|}
\hline $\begin{array}{l}\text { Questionnaire } \\
\text { category }\end{array}$ & Target respondents & Criteria & Information provided section wise \\
\hline \multirow[t]{5}{*}{$\begin{array}{l}\text { Community } \\
\text { level }\end{array}$} & \multirow{5}{*}{$\begin{array}{l}\text { Participants belonging } \\
\text { to a different gender } \\
\text { (male and female), age } \\
\text { group (i.e., } 16 \text { to } 45 \text { ), } \\
\text { and livelihoods (e.g., } \\
\text { agriculture, jobs such } \\
\text { as peons, clerks, } \\
\text { school teachers, } \\
\text { students, etc.), from } \\
\text { the habitation }\end{array}$} & Transport facility & $\begin{array}{l}\text { Travel and trip characteristics, the reliability of the } \\
\text { transport facility, passenger and freight charges }\end{array}$ \\
\hline & & Income status & $\begin{array}{l}\text { Change in income pattern, occupation, and availability of } \\
\text { any other income source to the participants as the impact } \\
\text { of new roads }\end{array}$ \\
\hline & & Health facility & $\begin{array}{l}\text { Impact of roads on quality and availability of health } \\
\text { services }\end{array}$ \\
\hline & & Education facility & $\begin{array}{l}\text { Impact of roads on the availability of education facility, } \\
\text { school enrollment, attendance and access }\end{array}$ \\
\hline & & $\begin{array}{l}\text { Quality of } \\
\text { neighborhood }\end{array}$ & $\begin{array}{l}\text { Changes in quality and life of neighborhood, expenditure, } \\
\text { and ownership of material property, as well as a change in } \\
\text { conditions of social inclusion within and outside the } \\
\text { community of the participants }\end{array}$ \\
\hline
\end{tabular}


All required data of Table 6 have been collected through focus group survey. The sample raw data for some selected habitations such as Bhagatia Ki Dhani, Dangiyo Ki Dhani, Sahali Ki Dhani, Khantato Ki Dhani, and Bugaliyon Ki Dhani located in Buhana block of Jhunjhunu district, Rajasthan is given in Appendix II. On similar lines, data with respect to other habitations are collected.

\subsection{Model assessment}

\section{Model Development (Training) for ANFIS}

In the present study, out-of-sample prediction technique is employed to assess the capability of the models. Accordingly, as mentioned earlier, the data set for each criterion is divided into two subsets with $70 \%$ of data set for training and $30 \%$ for testing. Five models are developed for each of the criteria (viz., transport facility, income status, health facility, education facility and quality of neighbourhood) separately and trained for the data set with the application of ANFIS tool of MATLAB 2016. To assess the performance of the developed model trial and error method is employed. The important parameters defining the ANFIS framework for quality of neighborhood model are listed below in Table 7. Fuzzy rules for the quality of the neighborhood model are shown in Figure 5. Membership functions of the subcriteria "involvement in social-gathering outside the village" ( $\left.Q_{\mathrm{SGOV}}\right)$ of quality of neighbourhood criteria are depicted as below in Figure 6. The parameters employed for ANFIS models are obtained from the literature (Islam et al., 2016; Keshavarzi et al., 2017).

Table 7. Parameters defining the ANFIS model for quality of neighborhood criteria

\begin{tabular}{|l|l|l|l|l|l|}
\hline S. No. & ANFIS Parameters & S. No. & \multicolumn{2}{l|}{ ANFIS Parameters } \\
\hline 1 & Number of input criteria & 5 & 7 & $\begin{array}{l}\text { Output layer transfer } \\
\text { function }\end{array}$ & Linear \\
\hline 2 & Number of layers & 5 & 8 & Epochs & 10 \\
\hline 3 & Training algorithm & Back propagation & 9 & Error tolerance & 0.0 \\
\hline 4 & Number of fuzzy rules & 12 & 10 & Membership function & Gaussian \\
\hline 5 & $\begin{array}{l}\text { Hidden layer transfer } \\
\text { function }\end{array}$ & Tansigmoid & 11 & FIS generated using & $\begin{array}{l}\text { Subtractive } \\
\text { clustering }\end{array}$ \\
\hline 6 & Sealing method & Normalization & & & \\
\hline
\end{tabular}

The output surface for the quality of the neighborhood model (QNA) is shown in Figure 7. It is also inferred from Figure 7, that as the input values ownership of personal phones $\left(\mathrm{Q}_{\mathrm{PPO}}\right)$ and ownership of television $\left(\mathrm{Q}_{\mathrm{TVO}}\right)$ sub-criterion are increased, the output value of quality of neighborhood model (QNA) also increases.

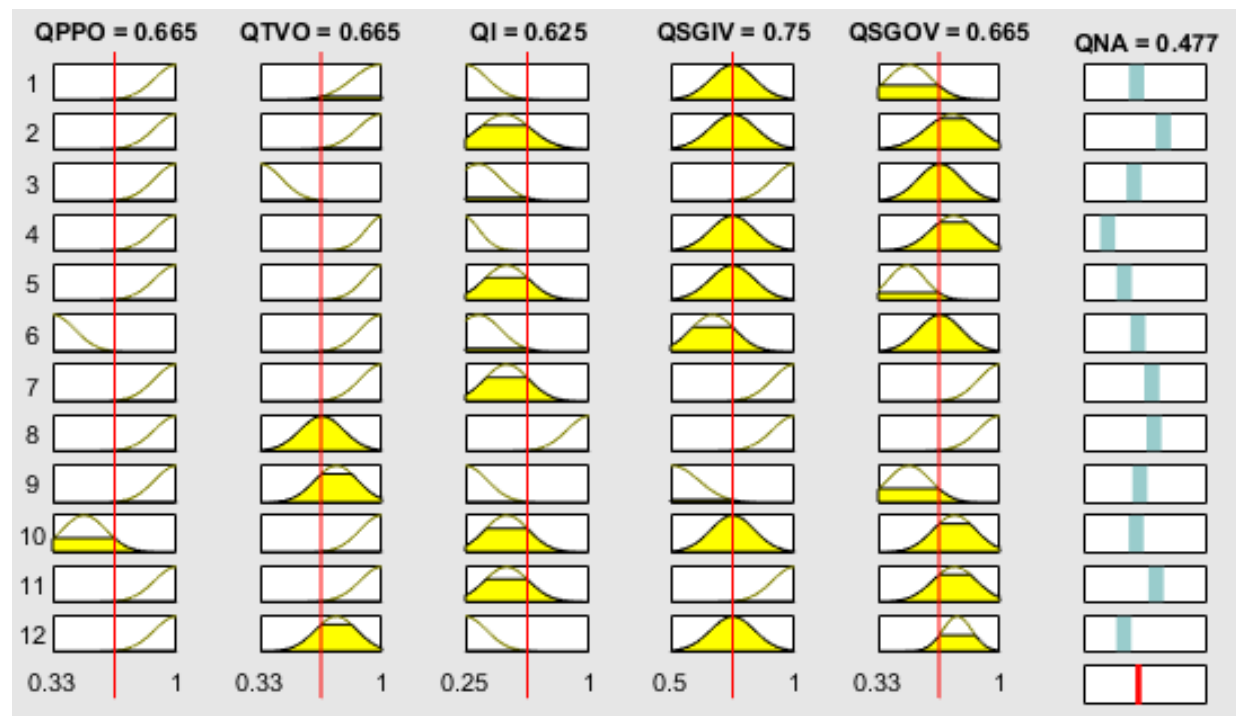

Figure 5. Rule view of ANFIS for training data of quality of neighborhood criteria 


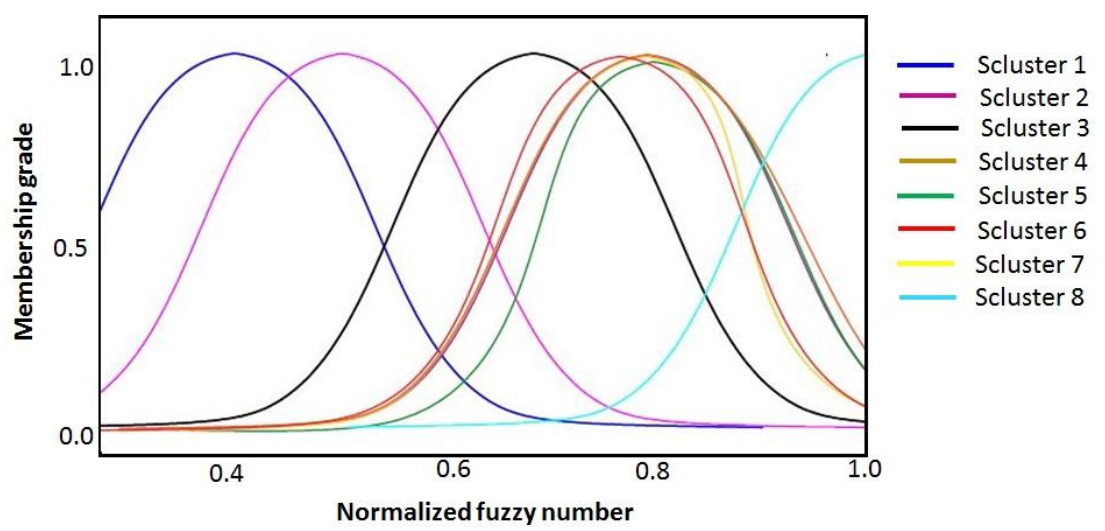

Figure 6. Membership functions of the sub-criteria "involvement in social-gathering outside the village"

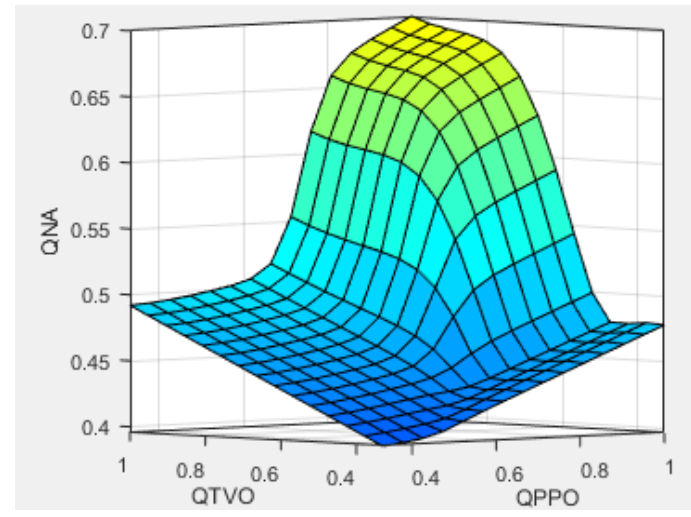

Figure 7. Output surface for quality of neighborhood criteria

\section{Model evaluation criteria}

In the current study, the performance of the models is evaluated by taking into account of two statistical criteria, viz., the correlation coefficient $(R)$ and the root-mean-square error $(R M S E)$, which can be expressed by equations (10) and (11) as mentioned below:

$R=\frac{\sum_{i=1}^{N}\left(t_{i}-t_{\text {avg }}\right) \times\left(p_{i}-p_{\text {avg }}\right)}{\sqrt{\sum_{i=1}^{N}\left(t_{i}-t_{\text {avg }}\right)^{2}} \times \sqrt{\sum_{i=1}^{N}\left(p_{i}-p_{a v g}\right)^{2}}}$,

where $t_{i}=i$ th target class, $t_{\text {avg }}=$ mean of target class, $p_{i}=i$ th predicted class, and $p_{\text {avg }}=$ mean of predicted class.

Root mean square error $=\sqrt{\frac{\sum_{i=1}^{N}\left(t_{i}-t_{\text {avg }}\right)^{2}}{N}}$,

where $\mathrm{N}$ is the total number of data observations.

\section{Results and discussions}

Five different models are developed with respect to each of the criteria (viz., transport facility, income status, health facility, education facility and quality of neighbourhood) using ANFIS and FDM techniques. To assess the socio-economic impacts incurred due to the construction of rural roads a case study of PMGSY roads is employed. For ANFIS modeling the data set is divided into two sections, viz., training data and testing data. The developed models are assessed on the basis of two evaluation criteria, viz., the correlation coefficient $(\mathrm{R})$ and the root mean square error (RMSE). Figure 8 illustrates the performance of the models for both testing and training data for ANFIS. The R-value for income status criteria model has been found high in both training and testing with the values of 0.7368 and 0.8621 respectively. The RMSE values have been found as 0.1152 and 0.1715 respectively, which are relatively low. Thus, the model performs better, as the value of R ranges between -1 to 1 and RMSE ranges between 
0 and 1, higher the $\mathrm{R}$ with lower RMSE value is a good fit. Moreover, the model for quality of neighbourhood criteria shows a similar pattern for the R and RMSE values for training are 0.9205 and 0.2617 respectively, whereas in testing, these values are 0.8389 and 0.1209 respectively.

From the analysis, it is observed that the models dealing with income status and quality of neighbourhood perform satisfactory as compared to the other models developed. The model for education facility shows low $\mathrm{R}$ values during both in training and testing phases, whereas the RMSE value for training model of education facility is high as compared to the RMSE values of all other models except for transport facility, which is also high but lower than education facility criteria model. The comparison of $\mathrm{R}$ and RMSE for training and testing data are shown in Figure 8.
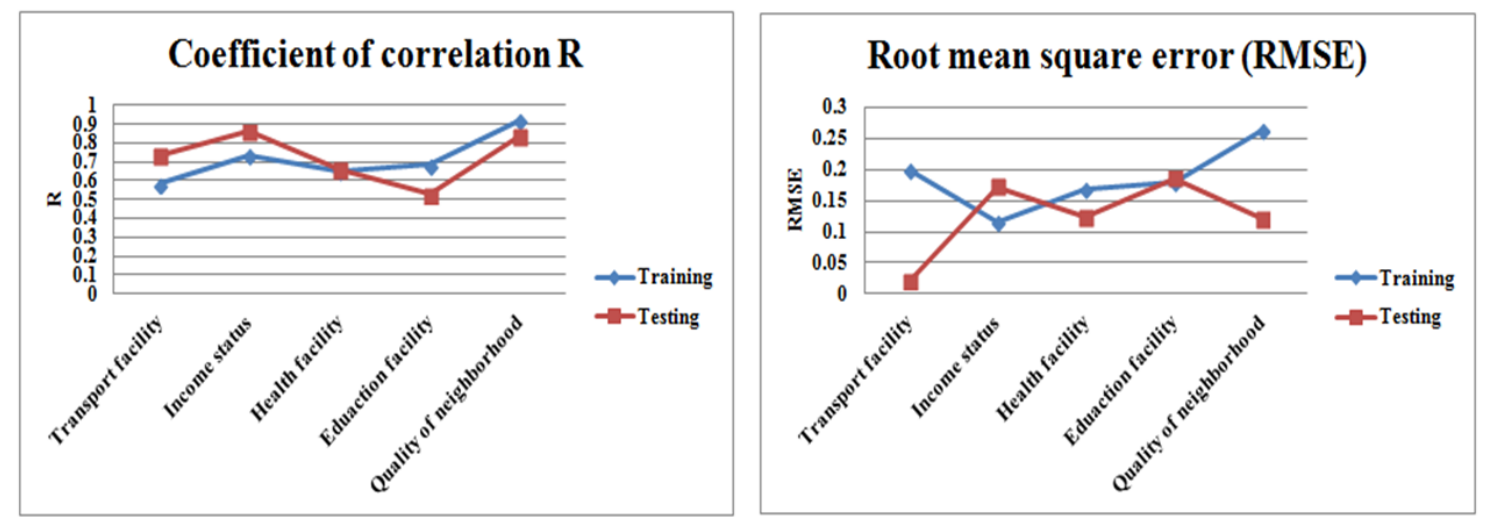

Figure 8. Comparison of the Correlation coefficient (R) and (RMSE) for training and testing data

Fuzzy Delphi method is applied to assess the socio-economic impacts incurred by the rural inhabitants due to the deliverance of rural (PMGSY) roads. From the assessment of FDM, it can be observed that values of best non-fuzzy performance score for quality of neighborhood criteria evaluated are in the range of 0.6 to 0.9 , which illustrates that the scores fall in the range of high category to an ultimately high category on the fuzzy scale as defined in Table 4. Therefore, it can be interpreted that the quality of life in the neighborhood of the rural habitants is impacted positively, which can be considered as one of the significant impacts generated by the deliverance of road infrastructure.

Furthermore, it can also be observed from the best non-fuzzy performance scores of income status criteria that they vary in the range of 0.51 to 1.0 , which resembles that the income status of rural habitants is impacted significantly. The income status criterion is defined by seven sub-criteria as mentioned in Table 2. From the results obtained for income status criteria model, it can be interpreted that inhabitants are being introduced to the new sources of income through increased production and better returns on the produce of agriculture or by other means.

Thus, there has been a positive change in income status criteria, leading to a significant change in the quality of neighborhood of rural habitants. Table 8 shows mean fuzzy weights and best non-fuzzy performance scores obtained for the quality of neighbourhood criteria.

Table 8. Mean fuzzy weights and best non-fuzzy performance score for quality of neighborhood criteria

\begin{tabular}{|l|l|l|l|l|l|l|l|l|l|}
\hline S. no. & \multicolumn{3}{|l|}{ Mean fuzzy weights } & \multicolumn{2}{l}{$\begin{array}{l}\text { Best non-fuzzy } \\
\text { performance score }\end{array}$} & \multicolumn{2}{l}{ S. no. } & \multicolumn{3}{l|}{ Mean fuzzy weights } & \multicolumn{2}{l|}{$\begin{array}{l}\text { Best non-fuzzy } \\
\text { performance score }\end{array}$} \\
\hline 1 & 0.56 & 0.67 & 0.71 & 0.65 & 15 & 0.65 & 0.75 & 0.79 & 0.73 \\
\hline 2 & 0.56 & 0.67 & 0.71 & 0.65 & 16 & 0.65 & 0.75 & 0.79 & 0.73 \\
\hline 3 & 0.56 & 0.67 & 0.71 & 0.65 & 17 & 0.65 & 0.75 & 0.83 & 0.74 \\
\hline 4 & 0.65 & 0.75 & 0.83 & 0.74 & 18 & 0.60 & 0.70 & 0.75 & 0.68 \\
\hline 5 & 0.75 & 0.85 & 0.89 & 0.83 & 19 & 0.82 & 0.93 & 0.95 & 0.90 \\
\hline 6 & 0.80 & 0.90 & 0.93 & 0.88 & 20 & 0.75 & 0.85 & 0.89 & 0.83 \\
\hline 7 & 0.71 & 0.80 & 0.85 & 0.79 & 21 & 0.75 & 0.85 & 0.89 & 0.83 \\
\hline 8 & 0.59 & 0.70 & 0.76 & 0.68 & 22 & 0.64 & 0.75 & 0.80 & 0.73 \\
\hline 9 & 0.71 & 0.80 & 0.85 & 0.79 & 23 & 0.70 & 0.80 & 0.87 & 0.79 \\
\hline 10 & 0.48 & 0.60 & 0.51 & 0.53 & 24 & 0.65 & 0.75 & 0.83 & 0.74 \\
\hline 11 & 0.55 & 0.65 & 0.72 & 0.64 & 25 & 0.85 & 0.95 & 0.96 & 0.92 \\
\hline 12 & 0.49 & 0.60 & 0.69 & 0.60 & 26 & 0.66 & 0.75 & 0.81 & 0.74 \\
\hline 13 & 0.59 & 0.70 & 0.76 & 0.68 & 27 & 0.85 & 0.95 & 0.96 & 0.92 \\
\hline 14 & 0.61 & 0.70 & 0.79 & 0.70 & & & & & \\
\hline
\end{tabular}


It has also been observed that education facility criteria has lower best performance non-fuzzy scores (ranging from low category to moderately low category) indicating that there is the least impact of road construction on overall education facility available to the residents, even though there is an increase in the percentage of school attendance of male and female students. The best performance non-fuzzy scores for transport and health facility range from low to moderately high category as shown in Table 9. Table 9 illustrates the best non-fuzzy performance score for all the criteria.

Table 9. Best performance score for criteria

\begin{tabular}{|c|c|c|c|c|c|}
\hline \multirow[t]{2}{*}{ S. no. } & \multicolumn{5}{|c|}{ Best non-fuzzy performance score } \\
\hline & Transport facility & Income status & Education facility & Health facility & Quality of neighborhood \\
\hline 1 & 0.51 & 0.51 & 0.32 & 0.61 & 0.65 \\
\hline 2 & 0.43 & 0.73 & 0.33 & 0.61 & 0.65 \\
\hline 3 & 0.37 & 0.62 & 0.45 & 0.42 & 0.65 \\
\hline 4 & 0.44 & 0.83 & 0.34 & 0.54 & 0.74 \\
\hline 5 & 0.44 & 0.89 & 0.20 & 0.66 & 0.83 \\
\hline 6 & 0.57 & 0.76 & 0.48 & 0.42 & 0.88 \\
\hline 7 & 0.39 & 0.58 & 0.55 & 0.49 & 0.79 \\
\hline 8 & 0.56 & 0.88 & 0.33 & 0.68 & 0.68 \\
\hline 9 & 0.56 & 0.73 & 0.44 & 0.65 & 0.79 \\
\hline 10 & 0.57 & 0.61 & 0.49 & 0.54 & 0.53 \\
\hline 11 & 0.57 & 0.74 & 0.43 & 0.47 & 0.64 \\
\hline 12 & 0.65 & 0.70 & 0.50 & 0.34 & 0.60 \\
\hline 13 & 0.45 & 0.70 & 0.51 & 0.42 & 0.68 \\
\hline 14 & 0.46 & 0.70 & 0.37 & 0.39 & 0.70 \\
\hline 15 & 0.51 & 0.70 & 0.33 & 0.54 & 0.73 \\
\hline 16 & 0.51 & 0.70 & 0.33 & 0.54 & 0.73 \\
\hline 17 & 0.39 & 0.88 & 0.34 & 0.58 & 0.74 \\
\hline 18 & 0.61 & 0.92 & 0.34 & 0.39 & 0.68 \\
\hline 19 & 0.34 & 0.79 & 0.40 & 0.43 & 0.90 \\
\hline 20 & 0.65 & 0.52 & 0.43 & 0.25 & 0.83 \\
\hline 21 & 0.67 & 0.65 & 0.52 & 0.47 & 0.83 \\
\hline 22 & 0.52 & 0.86 & 0.44 & 0.38 & 0.73 \\
\hline 23 & 0.73 & 0.65 & 0.30 & 0.35 & 0.79 \\
\hline 24 & 0.57 & 0.90 & 0.44 & 0.42 & 0.74 \\
\hline 25 & 0.45 & 0.83 & 0.50 & 0.47 & 0.92 \\
\hline 26 & 0.56 & 1.04 & 0.53 & 0.38 & 0.74 \\
\hline 27 & 0.51 & 0.94 & 0.46 & 0.30 & 0.92 \\
\hline
\end{tabular}
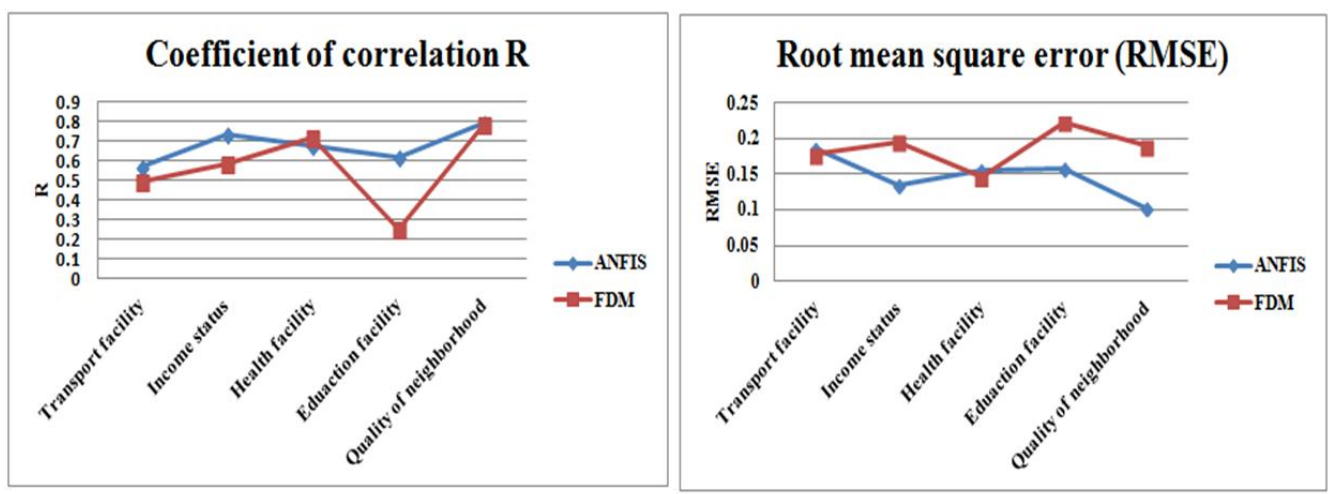

Figure 9. Comparison of the Correlation coefficient (R) and RMSE for ANFIS and FDM models

Moreover, from the analysis, it is observed that ANFIS models developed for the study outperforms in comparison to that of models developed with FDM, which can be seen from Figure 9. Furthermore, from the ANFIS analysis, the model developed for the health facility criteria is observed as least impacted criteria, about $40 \%$ of habitations show the moderately low impact on the health facility available to the inhabitants in the vicinity after the construction PMGSY roads, and same trend is observed in case of education facility criteria. One of the primary reasons for less impact on health facility and education facility criteria may be uneven distribution of facilities. However, significant impact is observed in case of quality of neighbourhood criteria, which signifies that with the advent of new roads there is a significant change in the quality of life. For better comprehension, the outcomes of 
ANFIS models are represented spatially by employing ArcGIS tool as shown below in Figures 10 to 12. The magnitude of impact due to the deliverance of PMGSY roads is depicted in the spatial representation as circles of varying sizes, larger the size of the circle indicates impact score is larger.

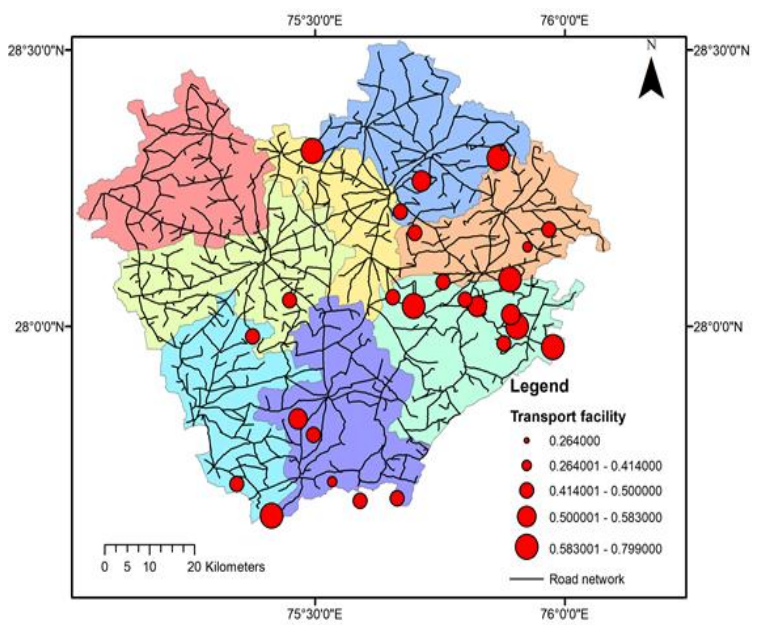

Figure 10. Spatial representation of the impact of PMGSY roads on transport facility criteria

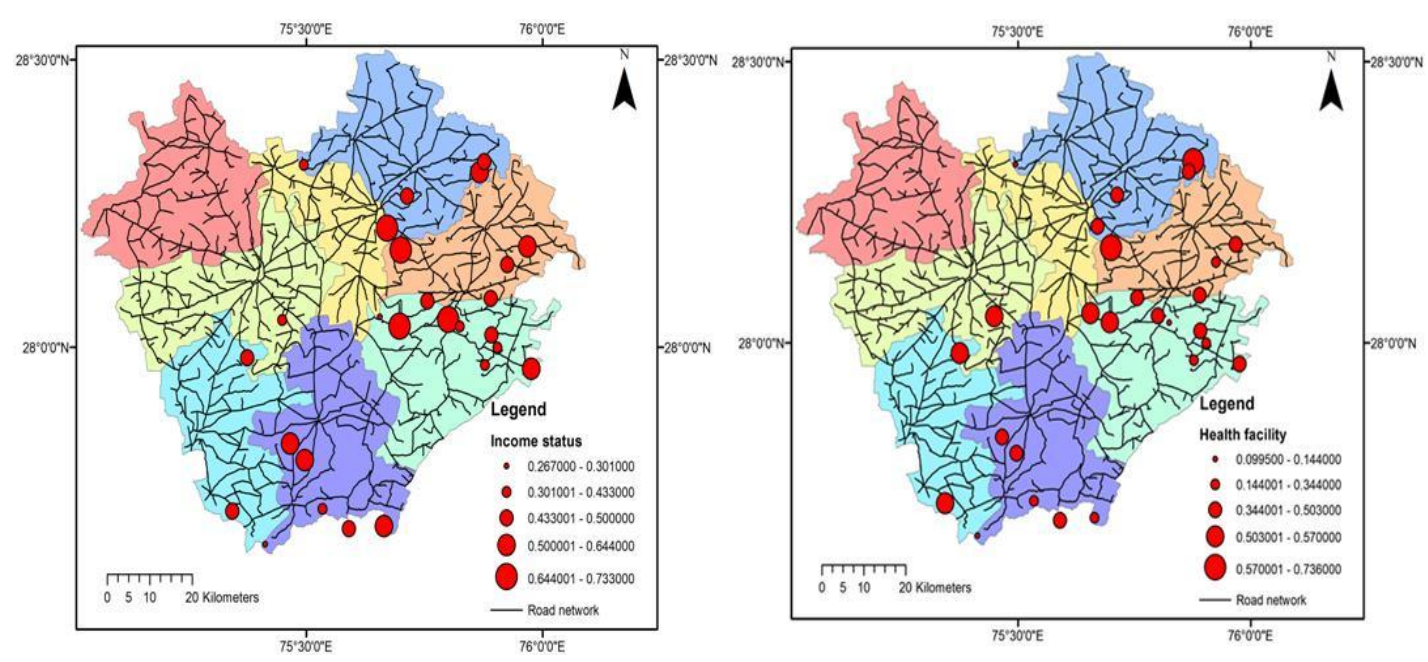

Figure 11. Spatial representation of the impact of PMGSY roads on income status and health facility criteria

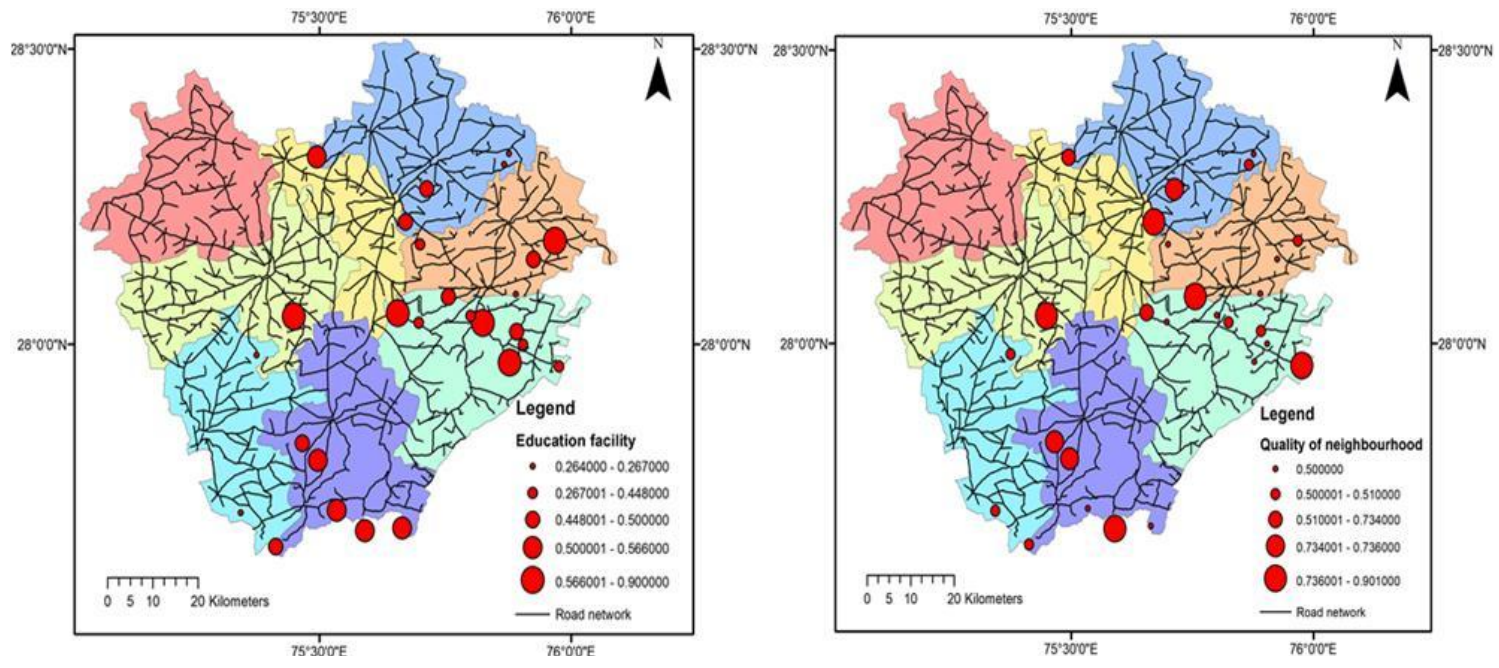

Figure 12. Spatial representation of the impact of PMGSY roads on education facility and quality of neighborhood criteria 


\section{Conclusion}

This study attempts to explore the impacts instigated due to the deliverance of rural (PMGSY) roads with respect to various criteria, viz., transport facility, income status, education facility, health facility and quality of the neighborhood, which contribute in enhancing the socio-economic development of the rural population. It also investigates the applicability of ANFIS technique based on subtractive clustering algorithm and fuzzy Delphi method for evaluating the socio-economic impacts of rural roads on the target population. Findings of the proposed methodology reveal that the income status and quality of neighborhood criteria show significant impacts, whereas health and education facility criteria show a lower impact. The models developed herein for income status and quality of neighbourhood criteria perform well using ANFIS and FDM modelling respectively. They are found to be effective in evaluating the necessary knowledge about the impacts instigated by the construction of the rural (PMGSY) roads. It depicts that quality of neighbourhood and income show positive impacts due to the deliverance of rural road infrastructure.

Owing to the positive impacts, it can be inferred that the habitants are able to avail different income opportunities, which in turn is assisting them to have stabilized income source and helping them to raise their social status. However, it is observed that the models for health and education facility criteria show lowest scores, which replicate less impact on the status of these facilities, available to inhabitants. Thus, indicating need of even distribution of social facilities available to rural inhabitants. Therefore, from value addition point of view, the analysis presented in this study will provide basis and understanding for decision-making authorities for implementing schemes and policies for enhancing the status of least impacted criteria. It has been observed that the quality of neighbourhood and income status are sensitive to the improvement of rural roads. The results of the proposed methodology will be helpful for concerned decision makers, to have a better view of ground conditions (i.e., change in the socioeconomic condition of rural households after the deliverance of roads), and will help them to intensify their focus on accomplishing the overall objective of rural development.

All-important findings of this study suggested that ANFIS models outperforms in comparison with the FDM models. Also, the developed model framework (ANFIS) can quantify the qualitative information, which exclusively is of subjective nature, and can handle real-world problem associated with uncertainties, as well as, it is time-cost effective. It also adds up as a significant technique to the SEIA literature.

\section{Appendix I}

Table A.1. Importance rating and value scale

\begin{tabular}{|l|l|}
\hline Importance rating & Scale value \\
\hline Very important & 5 \\
\hline Important & 4 \\
\hline Undecided & 3 \\
\hline Not important & 2 \\
\hline Not important at all & 1 \\
\hline
\end{tabular}

Table A.2. Expert opinion in terms of importance rating for identifying the criteria/sub-criteria

\begin{tabular}{|c|c|c|c|c|c|c|c|}
\hline \multirow[b]{2}{*}{ Criteria } & \multirow[b]{2}{*}{ Sub-criteria } & \multicolumn{6}{|c|}{ Experts } \\
\hline & & 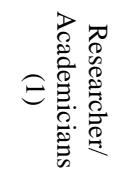 & 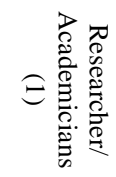 & 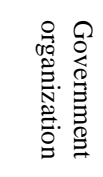 & 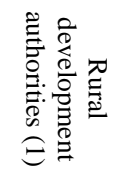 & 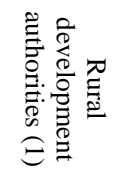 & 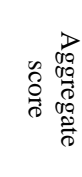 \\
\hline \multirow{8}{*}{$\begin{array}{l}\text { Transport } \\
\text { facility }\end{array}$} & $\begin{array}{l}\text { Travel time using public } \\
\text { transportation }\end{array}$ & 5 & 5 & 5 & 5 & 5 & 5 \\
\hline & $\begin{array}{l}\text { Travel time using private } \\
\text { transportation }\end{array}$ & 5 & 4 & 5 & 5 & 5 & 4.8 \\
\hline & Public transportation units & 4 & 4 & 5 & 5 & 5 & 4.6 \\
\hline & Private transportation units & 5 & 5 & 5 & 5 & 5 & 5 \\
\hline & $\begin{array}{l}\text { Frequency of Public } \\
\text { transportation }\end{array}$ & 4 & 4 & 5 & 5 & 5 & 4.8 \\
\hline & Public transportation cost & 4 & 4 & 5 & 5 & 5 & 4.8 \\
\hline & Private transportation cost & 4 & 5 & 5 & 5 & 5 & 4.8 \\
\hline & Road usability & 2 & 2 & 2 & 2 & 3 & 2.2 \\
\hline
\end{tabular}




\begin{tabular}{|c|c|c|c|c|c|c|c|}
\hline \multirow{2}{*}{ Criteria } & \multirow[b]{2}{*}{ Sub-criteria } & \multicolumn{6}{|c|}{ Experts } \\
\hline & & 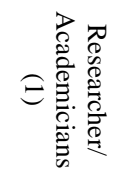 & 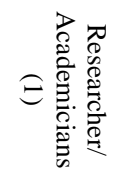 & 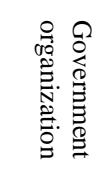 & 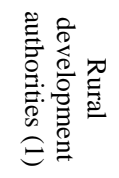 & 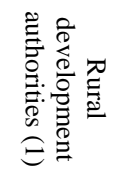 & 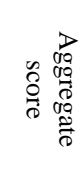 \\
\hline \multirow{8}{*}{ Income status } & Income of individual & 5 & 5 & 5 & 5 & 5 & 5 \\
\hline & Income of household & 5 & 5 & 5 & 5 & 5 & 5 \\
\hline & $\begin{array}{l}\text { Income of self-employed from } \\
\text { agriculture }\end{array}$ & 5 & 4 & 5 & 5 & 5 & 4.8 \\
\hline & $\begin{array}{l}\text { Income of wage labor from } \\
\text { agriculture }\end{array}$ & 4 & 4 & 5 & 5 & 5 & 4.6 \\
\hline & Income from livestock & 4 & 4 & 5 & 4 & 5 & 4.4 \\
\hline & $\begin{array}{l}\text { Income of self-employed from } \\
\text { non-agriculture }\end{array}$ & 1 & 1 & 3 & 2 & 2 & 1.8 \\
\hline & $\begin{array}{l}\text { Income of unskilled labor from } \\
\text { agriculture }\end{array}$ & 4 & 5 & 5 & 5 & 5 & 4.8 \\
\hline & $\begin{array}{l}\text { Income of unskilled labor from } \\
\text { non-agriculture }\end{array}$ & 4 & 4 & 5 & 5 & 5 & 4.6 \\
\hline \multirow{7}{*}{ Health facility } & Use of health facility & 4 & 4 & 5 & 5 & 5 & 4.6 \\
\hline & Availability of health clinic & 4 & 5 & 5 & 5 & 5 & 4.8 \\
\hline & $\begin{array}{l}\text { Availability of primary health } \\
\text { center }\end{array}$ & 4 & 4 & 5 & 5 & 5 & 4.6 \\
\hline & $\begin{array}{l}\text { Availability of community } \\
\text { health center }\end{array}$ & 1 & 1 & 1 & 1 & 1 & 1 \\
\hline & $\begin{array}{l}\text { Access to the mode of transport } \\
\text { for health facility }\end{array}$ & 5 & 5 & 5 & 5 & 5 & 5 \\
\hline & $\begin{array}{l}\text { Travel time to reach a health } \\
\text { facility }\end{array}$ & 4 & 4 & 5 & 5 & 5 & 4.6 \\
\hline & $\begin{array}{l}\text { Health Status (anthropometric } \\
\text { measures up to adolescent age) }\end{array}$ & 3 & 4 & 5 & 5 & 5 & 4.4 \\
\hline \multirow{10}{*}{$\begin{array}{l}\text { Education } \\
\text { Facility }\end{array}$} & Literacy rate of male & 4 & 5 & 5 & 5 & 5 & 4.8 \\
\hline & Literacy rate of female & 4 & 5 & 5 & 5 & 5 & 4.8 \\
\hline & $\begin{array}{l}\text { Percent of male children } \\
\text { attending schools }\end{array}$ & 5 & 5 & 5 & 5 & 5 & 5 \\
\hline & $\begin{array}{l}\text { Percent of female children } \\
\text { attending schools }\end{array}$ & 5 & 5 & 5 & 5 & 5 & 5 \\
\hline & $\begin{array}{l}\text { Access to the mode of transport } \\
\text { for education facility }\end{array}$ & 4 & 4 & 5 & 5 & 5 & 4.6 \\
\hline & $\begin{array}{l}\text { Travel time to reach education } \\
\text { facility }\end{array}$ & 5 & 5 & 5 & 5 & 5 & 5 \\
\hline & Availability of preschools & 3 & 3 & 5 & 5 & 5 & 4.2 \\
\hline & Availability of primary schools & 3 & 3 & 5 & 5 & 5 & 4.2 \\
\hline & $\begin{array}{l}\text { Availability of secondary } \\
\text { schools }\end{array}$ & 1 & 1 & 3 & 2 & 2 & 1.8 \\
\hline & Availability of girls schools & 1 & 1 & 3 & 3 & 2 & 2 \\
\hline \multirow{7}{*}{$\begin{array}{l}\text { Quality of } \\
\text { Neighborhood }\end{array}$} & $\begin{array}{l}\text { Availability of public telephone } \\
\text { service }\end{array}$ & 1 & 1 & 3 & 1 & 1 & 1.4 \\
\hline & Ownership of personal phone & 4 & 4 & 5 & 5 & 5 & 4.6 \\
\hline & Ownership of television & 4 & 4 & 5 & 5 & 4 & 4.4 \\
\hline & $\begin{array}{l}\text { Availability of public internet } \\
\text { facility }\end{array}$ & 1 & 1 & 3 & 3 & 2 & 2 \\
\hline & Livability & 5 & 5 & 5 & 5 & 5 & 5 \\
\hline & $\begin{array}{l}\text { Involvement in social-gathering } \\
\text { within the village }\end{array}$ & 4 & 5 & 5 & 5 & 5 & 4.8 \\
\hline & $\begin{array}{l}\text { Involvement in social-gathering } \\
\text { outside the village }\end{array}$ & 4 & 4 & 5 & 5 & 5 & 4.6 \\
\hline
\end{tabular}




\section{Appendix II}

Each of the sub-criteria associated with the main criteria is assessed on a scale of 5 down to 1 (i.e., $5=$ highest change; 4 = high change; 3 = moderate change; $2=$ low change; $1=$ lowest change), based on the perception of the focus group.

Table A.II.1. Perception of the focus group on Transport facility criteria

\begin{tabular}{|c|c|c|c|c|c|c|c|}
\hline Habitations & $\begin{array}{l}\text { Travel time } \\
\text { using public } \\
\text { transportation } \\
\left(\mathrm{T}_{\text {TTPUB }}\right)\end{array}$ & $\begin{array}{l}\text { Travel time } \\
\text { using private } \\
\text { transportation } \\
\left(\mathrm{T}_{\text {TTPVT }}\right)\end{array}$ & $\begin{array}{l}\text { Public } \\
\text { transportation } \\
\text { units }\left(\mathrm{T}_{\mathrm{PUBTU}}\right)\end{array}$ & $\begin{array}{l}\text { Private } \\
\text { transportation } \\
\text { units }\left(\mathrm{T}_{\text {PVTTU }}\right)\end{array}$ & $\begin{array}{l}\text { Frequency of } \\
\text { public } \\
\text { transportation } \\
\left(\mathrm{T}_{\mathrm{PUBF}}\right)\end{array}$ & $\begin{array}{l}\text { Public } \\
\text { transportation } \\
\text { cost }\left(\mathrm{T}_{\text {PUBTC }}\right)\end{array}$ & $\begin{array}{l}\text { Private } \\
\text { transportation } \\
\text { cost }\left(\mathrm{T}_{\text {PVTTC }}\right)\end{array}$ \\
\hline $\begin{array}{l}\text { Bhagatia } \\
\text { Ki Dhani }\end{array}$ & 5 & 4 & 3 & 3 & 5 & 3 & 4 \\
\hline $\begin{array}{l}\text { Dangiyo } \\
\text { Ki Dhani }\end{array}$ & 1 & 3 & 1 & 4 & 1 & 3 & 5 \\
\hline $\begin{array}{l}\text { Sahali Ki } \\
\text { Dhani }\end{array}$ & 3 & 3 & 1 & 3 & 3 & 2 & 3 \\
\hline $\begin{array}{l}\text { Khantato } \\
\text { Ki Dhani }\end{array}$ & 3 & 3 & 2 & 2 & 3 & 3 & 3 \\
\hline $\begin{array}{l}\text { Bugaliyon } \\
\text { Ki Dhani }\end{array}$ & 3 & 3 & 2 & 2 & 4 & 2 & 3 \\
\hline
\end{tabular}

Table A.II.2. Perception of the focus group on Income status criteria

\begin{tabular}{|c|c|c|c|c|c|c|c|}
\hline Habitations & $\begin{array}{l}\text { Income of } \\
\text { individual } \\
\left(\mathrm{I}_{\mathrm{III}}\right)\end{array}$ & $\begin{array}{l}\text { Income of } \\
\text { household } \\
\left(\mathrm{I}_{\mathrm{IHH}}\right)\end{array}$ & $\begin{array}{l}\text { Income of self- } \\
\text { employed from } \\
\text { agriculture } \\
\text { (IISA) }\end{array}$ & $\begin{array}{l}\text { Income of } \\
\text { wage labor } \\
\text { from } \\
\text { agriculture } \\
\left(\mathrm{I}_{\text {IWA }}\right)\end{array}$ & $\begin{array}{l}\text { Income } \\
\text { from } \\
\text { livestock } \\
\left(\mathrm{I}_{\mathrm{IL}}\right)\end{array}$ & $\begin{array}{l}\text { Income of } \\
\text { unskilled } \\
\text { labor from } \\
\text { agriculture } \\
\left(\mathrm{I}_{\mathrm{IUA}}\right)\end{array}$ & $\begin{array}{l}\text { Income of } \\
\text { unskilled } \\
\text { labor from } \\
\text { non- } \\
\text { agriculture } \\
\left(\mathrm{I}_{\text {IUNA }}\right)\end{array}$ \\
\hline Bhagatia Ki Dhani & 4 & 5 & 3 & 3 & 3 & 3 & 2 \\
\hline Dangiyo Ki Dhani & 4 & 5 & 4 & 2 & 4 & 3 & 4 \\
\hline Sahali Ki Dhani & 5 & 4 & 3 & 3 & 3 & 4 & 3 \\
\hline Khantato Ki Dhani & 4 & 4 & 4 & 4 & 3 & 3 & 4 \\
\hline $\begin{array}{l}\text { Bugaliyon Ki } \\
\text { Dhani }\end{array}$ & 5 & 5 & 3 & 3 & 4 & 3 & 3 \\
\hline
\end{tabular}

Table A.II.3. Perception of the focus group on health facility criteria

\begin{tabular}{|c|c|c|c|c|c|c|}
\hline Habitations & $\begin{array}{l}\text { Use of } \\
\text { health } \\
\text { facility } \\
\left(\mathrm{H}_{\mathrm{FU}}\right)\end{array}$ & $\begin{array}{l}\text { Availability } \\
\text { of health } \\
\text { clinic }\left(\mathrm{H}_{\mathrm{CA}}\right)\end{array}$ & $\begin{array}{l}\text { Availability of } \\
\text { primary health } \\
\text { center }\left(\mathrm{P}_{\mathrm{HCA}}\right)\end{array}$ & $\begin{array}{l}\text { Access to the } \\
\text { mode of } \\
\text { transport for } \\
\text { health facility } \\
\left(\mathrm{H}_{\mathrm{AM}}\right)\end{array}$ & $\begin{array}{l}\text { Travel time } \\
\text { to reach a } \\
\text { health } \\
\text { facility }\left(\mathrm{H}_{\mathrm{TT}}\right)\end{array}$ & $\begin{array}{l}\text { Health Status } \\
\text { (anthropometric } \\
\text { measures up to } \\
\text { adolescent age) } \\
\text { (H HSANT) }\end{array}$ \\
\hline Bhagatia Ki Dhani & 5 & 2 & 2 & 5 & 1 & 3 \\
\hline Dangiyo Ki Dhani & 4 & 1 & 2 & 4 & 2 & 3 \\
\hline Sahali Ki Dhani & 4 & 1 & 1 & 3 & 5 & 3 \\
\hline Khantato Ki Dhani & 5 & 2 & 1 & 3 & 2 & 3 \\
\hline Bugaliyon Ki Dhani & 3 & 1 & 1 & 3 & 3 & 4 \\
\hline
\end{tabular}


Table A.II.4. Perception of the focus group on education facility criteria

\begin{tabular}{|l|l|l|l|l|l|l|l|l|}
\hline Habitations & $\begin{array}{l}\text { Literacy } \\
\text { rate of } \\
\text { male } \\
\left(\mathrm{E}_{\mathrm{MLR}}\right)\end{array}$ & $\begin{array}{l}\text { Literacy } \\
\text { rate of } \\
\text { female } \\
\left(\mathrm{E}_{\mathrm{FLR}}\right)\end{array}$ & $\begin{array}{l}\text { Percent of } \\
\text { male } \\
\text { children } \\
\text { attending } \\
\text { schools } \\
\left(\mathrm{E}_{\mathrm{MAS}}\right)\end{array}$ & $\begin{array}{l}\text { Percent of } \\
\text { female } \\
\text { children } \\
\text { attending } \\
\text { schools } \\
\left(\mathrm{E}_{\mathrm{FAS}}\right)\end{array}$ & $\begin{array}{l}\text { Access to } \\
\text { the mode } \\
\text { of transport } \\
\text { for } \\
\text { education } \\
\text { facility } \\
\left(\mathrm{E}_{\mathrm{AM}}\right)\end{array}$ & $\begin{array}{l}\text { Travel } \\
\text { time to } \\
\text { reach } \\
\text { education } \\
\text { facility } \\
\left(\mathrm{E}_{\mathrm{TT}}\right)\end{array}$ & $\begin{array}{l}\text { Availability } \\
\text { of } \\
\text { preschools } \\
\text { (ERESA }\end{array}$ & $\begin{array}{l}\text { Availability } \\
\text { of primary } \\
\text { schools } \\
\left(\mathrm{E}_{\mathrm{PRISA}}\right)\end{array}$ \\
\hline $\begin{array}{l}\text { Bhagatia Ki } \\
\text { Dhani }\end{array}$ & 3 & 3 & 4 & 4 & 5 & 1 & 1 \\
\hline $\begin{array}{l}\text { Dangiyo Ki } \\
\text { Dhani }\end{array}$ & 3 & 2 & 4 & 4 & 3 & 1 & 1 \\
\hline $\begin{array}{l}\text { Sahali Ki } \\
\text { Dhani }\end{array}$ & 2 & 3 & 4 & 3 & 5 & 5 & 2 \\
\hline $\begin{array}{l}\text { Khantato Ki } \\
\text { Dhani }\end{array}$ & 3 & 2 & 5 & 4 & 3 & 2 & 2 \\
\hline $\begin{array}{l}\text { Bugaliyon Ki } \\
\text { Dhani }\end{array}$ & 3 & 2 & 5 & 5 & 3 & 2 & 2 \\
\hline
\end{tabular}

Table A.II.5. Perception of the focus group on quality of neighborhood criteria

\begin{tabular}{|c|c|c|c|c|c|}
\hline Habitations & $\begin{array}{l}\text { Ownership of } \\
\text { personal phone } \\
\left(Q_{\mathrm{PPO}}\right)\end{array}$ & $\begin{array}{l}\text { Ownership of } \\
\text { Television } \\
\left(Q_{\text {TVO }}\right)\end{array}$ & $\begin{array}{l}\text { Livability } \\
\left(Q_{L}\right)\end{array}$ & $\begin{array}{l}\text { Involvement in } \\
\text { Social-gathering } \\
\text { within the village } \\
\left.\text { (Q } Q_{\text {SGIV }}\right)\end{array}$ & $\begin{array}{l}\text { Involvement in } \\
\text { Social-gathering } \\
\text { outside the village } \\
\left(Q_{\text {SGOV }}\right)\end{array}$ \\
\hline Bhagatia Ki Dhani & 4 & 3 & 4 & 4 & 4 \\
\hline Dangiyo Ki Dhani & 4 & 3 & 3 & 4 & 3 \\
\hline Sahali Ki Dhani & 4 & 4 & 4 & 5 & 4 \\
\hline Khantato Ki Dhani & 5 & 5 & 3 & 4 & 3 \\
\hline Bugaliyon Ki Dhani & 5 & 5 & 3 & 5 & 4 \\
\hline
\end{tabular}

\section{References}

1. Aderamo, A. J., and Magaji, S. A. (2010) Rural transportation and the distribution of public facilities in Nigeria: a case of Edu local government area of Kwara State. Journal of Human Ecology, 29, 171-179. DOI:10.1080/09709274.2010.11906260.

2. Akbulut, S., Hasiloglu, A. S., and Pamukcu, S. (2004) Data generation for shear modulus and damping ratio in reinforced sands using adaptive neuro-fuzzy inference system. Soil Dynamics and Earthquake Engineering, 24(11), 805-814. DOI:10.1016/j.soildyn.2004.04.006.

3. Andrade, K., Uchida, K., and Kagaya, S. (2006) Development of transport mode choice model by using adaptive neuro-fuzzy inference system. Transportation Research Record: Journal of the Transportation Research Board, 1977, 8-16. DOI:10.3141/1977-04.

4. Asomani-Boateng, R., Fricano, R. J., and Adarkwa, F. (2015) Assessing the socio-economic impacts of rural road improvements in Ghana: A case study of Transport Sector Program Support (II). Journal of Case Studies on Transport Policy, 3, 355-366. DOI:10.1016/j.cstp.2015.04.006.

5. Baker, J. L. (2000) Evaluating the impact of development projects on poverty: A handbook for practitioners, Washington, D. C.: World Bank Publications.

6. Banister, D., and Berechman, Y. (2000) The economic development effects of transport investments, London: University College London Press.

7. Braathen, S., and Hervik, A. (1997) Strait Crossings and Economic Development - Developing Economic Impact Assessment by Means of Ex-post Analyses. Transport Policy, 4, 193-200. DOI:10.1016/S0967-070X(97)00017-6.

8. Chang, N. B., and Wei, Y. L. (2000) Siting recycling drop-off stations in urban area by genetic algorithm-based fuzzy multi-objective nonlinear integer programming modeling. Fuzzy Sets and Systems, 114, 133-149. DOI:10.1016/S0165-0114(98)00192-4. 
9. Dalkey, N., and Helmer, O. (1963) An experimental application of the Delphi method to the use of experts. Management Science, 9, 458-467.

10. Edelman, M. J. (1985) The symbolic uses of politics, USA: University of Illinois Press UrbanaChampaign.

11. Grootaert, C., and Calvo, C. M. (2002) Socio-economic impact assessment of rural roads: methodology and questionnaires, Washington, D. C.: INFTD, World Bank.

12. Hosseinlou, M. H., and Sohrabi, M. (2009) Predicting and identifying traffic hot spots applying neuro-fuzzy systems in intercity roads. International Journal of Environmental Science \& Technology, 6, 309-314. DOI:10.1007/BF03327634.

13. Hsu, Y. L., Lee, C. H., and Kreng, V. B. (2010) The application of Fuzzy Delphi Method and Fuzzy AHP in lubricant regenerative technology selection. Expert Systems with Application, 37, 419-425. DOI:10.1016/j.eswa.2009.05.068.

14. Islam, R., Musabbir, S. R., Ahmed, I. U., Hadiuzzaman, M., Hasnat, M., and Hossain, S. (2016) Bus service quality prediction and attribute ranking using probabilistic neural network and adaptive neuro fuzzy inference system. Canadian Journal of Civil Engineering, 43, 822-829. DOI:10.1139/cjce-2016-0119.

15. Jang, J. S. (1993) ANFIS: adaptive-network-based fuzzy inference system. IEEE Transactions on Systems, Man, and Cybernetics, 23, 665-685.

16. Kanuganti, S., Sarkar, A. K., and Singh, A. P. (2016) Evaluation of access to health care in rural areas using enhanced two-step floating catchment area (E2SFCA) method. Journal of Transport Geography, 56, 45-52. DOI:10.1016/j.jtrangeo.2016.08.011.

17. Kanuganti, S., Sarkar, A. K., Singh, A. P. and Arkatkar, S. S. (2015) Quantification of Accessibility to Health Facilities in Rural Areas, Journal of Case Studies on Transport Policy, 3(3), 311-320.

18. Keshavarzi, A., Sarmadian, F., Shiri, J., Iqbal, M., Tirado-Corbalá, R., and Omran, E.S.E. (2017) Application of ANFIS-based subtractive clustering algorithm in soil cation exchange capacity estimation using soil and remotely sensed data. Measurement, 95, 173-180. DOI:10.1016/j.measurement.2016.10.010.

19. Khandker, S. R., Bakht, Z., and Koolwal, G. B. (2009) The poverty impact of rural roads: evidence from Bangladesh. Economic Development and Cultural Change, 57, 685-722. DOI:10.1086/598765.

20. Khandker S. R., and Koolwal, G. B. (2011) Estimating the long-term impacts of rural roads: a dynamic panel approach, Washington, D. C.: World Bank Publication.

21. Kaufmann, A., and Gupta, M. M. (1988) Fuzzy mathematical models in engineering and management science, North-Holland: Elsevier Science Publishers.

22. Lee, S., Wong, S. C., and Li, Y. C. (2015) Real-time estimation of lane-based queue lengths at isolated signalized junctions. Transportation Research Part C: Emerging Technologies, 56, 1-17. DOI: $10.1016 /$ j.trc.2015.03.019.

23. Liu, W. K. (2013) Application of the Fuzzy Delphi Method and the Fuzzy Analytic Hierarchy Process for the Managerial Competence of Multinational Corporation Executives. International Journal of e-Education, e-Business, e-Management, and e-Learning, 3, 313. DOI:10.7763/IJEEEE. 2013.V3.248.

24. Louwa, E., Leijtenb, M., and Meijersa, E. (2013) Changes subsequent to infrastructure investments: Forecasts, expectations and ex-post situation. Transport Policy, 29, 107-117. DOI:10.1016/j.tranpol.2013.04.012.

25. Mamdani, E. H., and Assilian, S. (1975) An experiment in linguistic synthesis with a fuzzy logic controller. International Journal of Man-Machine. Studies, 7, 1-13. DOI:10.1016/S0020-7373(75)80002-2.

26. MATLAB and Statistics Toolbox Release. (2016) The MathWorks, Inc., Natick, Massachusetts, United States.

27. Mucsi, K., Khan, A. M., and Ahmadi, M. (2011) An adaptive neuro fuzzy inference system for estimating the number of vehicles for queue management at signalized intersections. Transportation Research Part C: Emerging Technologies, 19, 1033-1047. DOI:10.1016/j.trc.2011.05.016.

28. Nirban, V. S., Metri, B. A., Singh, A. P., and Sarkar, A. K. (2003) Socioeconomic Benefits of PMGSY Projects: Perceptions of Rural Community. In: Proceedings of a Seminar on Integrated Development of Rural and Arterial Road Network for Socio-Economic Growth, New Delhi, December 2003, 166-173.

29. Pamučar, D., Lukovac, V., and Pejčić-Tarle, S. (2013) Application of adaptive neuro fuzzy inference system in the process of transportation support. Asia-Pacific Journal of Operational Research, 30. DOI:10.1142/S0217595912500534.

30. Phogat V. S. M., and Singh, A. P. (2013) Selection of Equipment for Construction of a Hilly Road Using Multi Criteria Approach. Procedia - Social and Behavioral Sciences, 104, 282-291. 
31. Pribyl, O. and Goulias, K. G. (2003) Application of adaptive neuro fuzzy inference system to analysis of travel behavior. Transportation Research Record: Journal of the Transportation Research Board, 1854, 180-188. DOI:10.3141/1854-20.

32. Relich, M., and Pawlewski, P. (2016) A Multi-agent Framework for Cost Estimation of Product Design, In: International Conference on Practical Applications of Agents and Multi-Agent Systems, Cham: Springer, 102-114.

33. Singh, A. P., and Vidyarthi, A. K. (2008) Optimal allocation of landfill disposal site: A fuzzy multicriteria approach. Journal of Environmental and Health Science and Engineering, 5, 25-34.

34. Tahriri, F., Mousavi, M., Haghighi, S.H., and Dawal, S. Z. M. (2014) The application of fuzzy Delphi and fuzzy inference system in supplier ranking and selection. Journal of Industrial Engineering International, 10(3). DOI:10.1007/s40092-014-0066-6.

35. Takagi, T., and Sugeno, M. (1985) Fuzzy identification of systems and its applications to modelling and control. IEEE Transactions on Systems, Man, and Cybernetics, 15, 116-132.

36. Tortum, A., Yayla, N., and Gökda, M. (2009) The modelling of mode choices of intercity freight transportation with the artificial neural networks and adaptive neuro-fuzzy inference system. Expert Systems with Applications, 36, 6199-6217. DOI: 10.1016/j.eswa.2008.07.032.

37. Tunde, A. M., and Adeniyi, E. E. (2012) Impact of road transport on agricultural development: A Nigerian example. Ethiopian of Journal of Environmental Studies and Management, 5, 232-238. DOI:10.4314/ejesm.v5i3.3.

38. Wagale, M., Singh, A. P., and Singh, A. (2016) Neural networks approach for evaluating quality of service in public transportation in rural areas. In: Information Processing (IICIP), 1st India International Conference, IEEE, New Delhi, India, August 2016, 1-5. DOI:10.1109/IICIP.2016.7975391.

39. Wagale M., Singh, A. P., and Sarkar, A. K. (2019) Impact of rural road construction on the local livelihood diversification: Evidence from Pradhan Mantri Gram Sadak Yojana in Jhunjhunu district, India. GeoJournal, Springer. DOI:10.1007/s10708-019-10007-3. 